University of South Florida

DIGITAL COMMONS Digital Commons @ University of @ UNIVERSITY OF SOUTH FLORIDA South Florida

\title{
Media Framing of Fatal Bicycle Crashes in Hillsborough County: A Critical Discourse Analysis
}

CUTR

Follow this and additional works at: https://digitalcommons.usf.edu/cutr_nctr

\section{Recommended Citation}

"Media Framing of Fatal Bicycle Crashes in Hillsborough County: A Critical Discourse Analysis," National Center for Transit Research (NCTR) Report No. CUTR-NCTR-RR-2018-01, Center for Urban Transportation Research, University of South Florida, 2018.

DOI: https://doi.org/10.5038/CUTR-NCTR-RR-2018-01

Available at: https://scholarcommons.usf.edu/cutr_nctr/9

This Technical Report is brought to you for free and open access by the National Center for Transit Research (NCTR) Archive (2000-2020) at Digital Commons @ University of South Florida. It has been accepted for inclusion in Research Reports by an authorized administrator of Digital Commons @ University of South Florida. For more information, please contact digitalcommons@usf.edu. 
Final Report CUTR-2018-09

\title{
Media Framing of Fatal Bicycle Crashes in Hillsborough County: A Critical Discourse Analysis
}

\author{
Prepared For: \\ National Center for Transit Research \\ at the Center for Urban Transportation Reserach
}

\author{
Julie Bond, MPA \\ Erin Scheffels, PhD \\ Lorraine Monteagut, PhD
}

September 2018

\section{CUTR USF LNVVERTY YF}




\section{INTRODUCTION}

TAMPA - A man wearing dark clothing and riding a bicycle was killed when he was hit by a car early Sunday on Hillsborough Avenue. The accident happened about 5 a.m. at the intersection with Lois Avenue. Jerome Thomas, 44, was riding a bike north, across Hillsborough Avenue, about 300 feet west of the intersection, when he was hit by a car in the eastbound lanes, according to Tampa police. Thomas died at the scene. The car's driver, Lorenzo Rodriguez, 57, was not issued any traffic citations, police said (Tampa Bay Times, 2014).

The language in the above report from the Tampa Bay Times is typical of traffic crash reports. Though this might seem a straightforward presentation of the "facts” of the event, discourse analysis reveals a multitude of language choices, conscious and unconscious, that reflect and potentially influence local understandings of fatal crashes involving bicyclists. For instance, the first sentence in the report demonstrates an active structure: transitive verbs (wearing, riding, killed), a human subject (a man), and an object (he) which undergoes change through the process described by the verbs (killed when he was hit by a car). Word and sentence constructions such as these are choices, and there are many different choices a reporter or writing may employ; examining those choices, then, could provide insight into local culture and inform future reporting, shifting the way social actors approach the problem of bicyclist deaths.

In the first sentence of the report, the man who was killed by a motorist is an actor or agent and is both the subject and the object in the sentence. He is in control of choices that have caused the process of being hit and killed by a car to unfold. The motorist is omitted from the sentence and replaced with a passive, inanimate object (hit by a car), and the bicyclist’s relationships to others and his environment are omitted as well, while his responsibility as an individual is not. The language choices of the authors frame the man on the bicycle as separate 
from (rather than related to) the motorist, the police, the engineers, the planners of local infrastructure, the newspaper readership, or the newspaper itself.

The purpose of this project is to examine the linguistic choices (e.g., vocabulary, grammar, structure) that frame the relationships between bicyclists and other parties involved in fatal crash events, while attending to identity constructions of social actors and interrogating sociocultural contexts (i.e., policy and economy). Through critical discourse analysis (CDA), a rigorous qualitative method that is used to analyze both oral and written communication, researchers identify how linguistic choices form patterns that (re)occur and (re)produce systems of meaning that shape urban landscapes and the social identities of bicyclists and motorists. CDA reveals the "common sense" or "taken-for-granted" lexicon of transportation by examining the nuances of language. Discourse analysts identify language as a site of ideological struggle, putting emphasis on creative outcomes and the prospect of social change. This interdisciplinary study is a unique contribution to transportation literature as it employs a methodology that is typically reserved for communication scholars and linguists.

In this study, textual data were collected via media reports of bicyclist traffic fatalities in Hillsborough County, Florida. The Tampa Bay Area has a disproportionately high number of bicyclist and pedestrian fatalities in comparison to other areas of the United States, making it an appropriate and necessary site of transportation inquiry. From January 2009 to June 2018, there were 94 bicyclist fatalities in Hillsborough County. The fatalities reported in Hillsborough County within this ten-year timespan were compiled for coding and analysis, and the bicyclists and drivers identified by names, dates, and locations of crashes. The news reports were coded with software designed for qualitative research, which helped the researchers locate and record repeated textual features in a large quantity of data. Data were then analyzed using Norman 
Fairclough’s procedure for critical discourse analysis (1989; 2003) to enhance understandings of transportation culture in Hillsborough County.

The objectives of the research are to 1.) illustrate the nuances of language that shape (and are shaped by) institutional contexts to maintain social order; 2.) evaluate the social effects of a “common sense” or "taken-for-granted” lexicon of transportation; and 3.) develop strategies for participating in transit-related language practices with the aim of altering public perceptions of bicycle fatalities.

\section{Background}

According to NHTSA, the number of bicyclist deaths in the U.S. increased by 1.3 percent to 840 during 2016 from the previous year, the highest since 1991. Florida consistently leads the nation with the highest rate of bicyclist deaths per capita, reporting 16.6 percent of total U.S. bicyclist deaths during 2016 (National Highway Traffic Safety Administration, 2016a). Hillsborough County, Florida, located mid-state along the western boundary, is the geographic location for this research. Home to 1.4 million residents, the county has a larger population than ten other U.S. states. The county seat and largest city is Tampa (United States Census Bureau, 2017).

As illustrated in Figure 1, from 2009 through 2016, Hillsborough County, alone, had a higher average rate of bicyclist fatalities than Florida's rate, spiking at 10.92 fatalities per million during 2012 (Florida’s Integrated Report Exchange System, 2018). When compared to the nation, and populous states such as California, Hillsborough County's rate was also higher (National Highway Traffic Safety Administration, 2016b). 


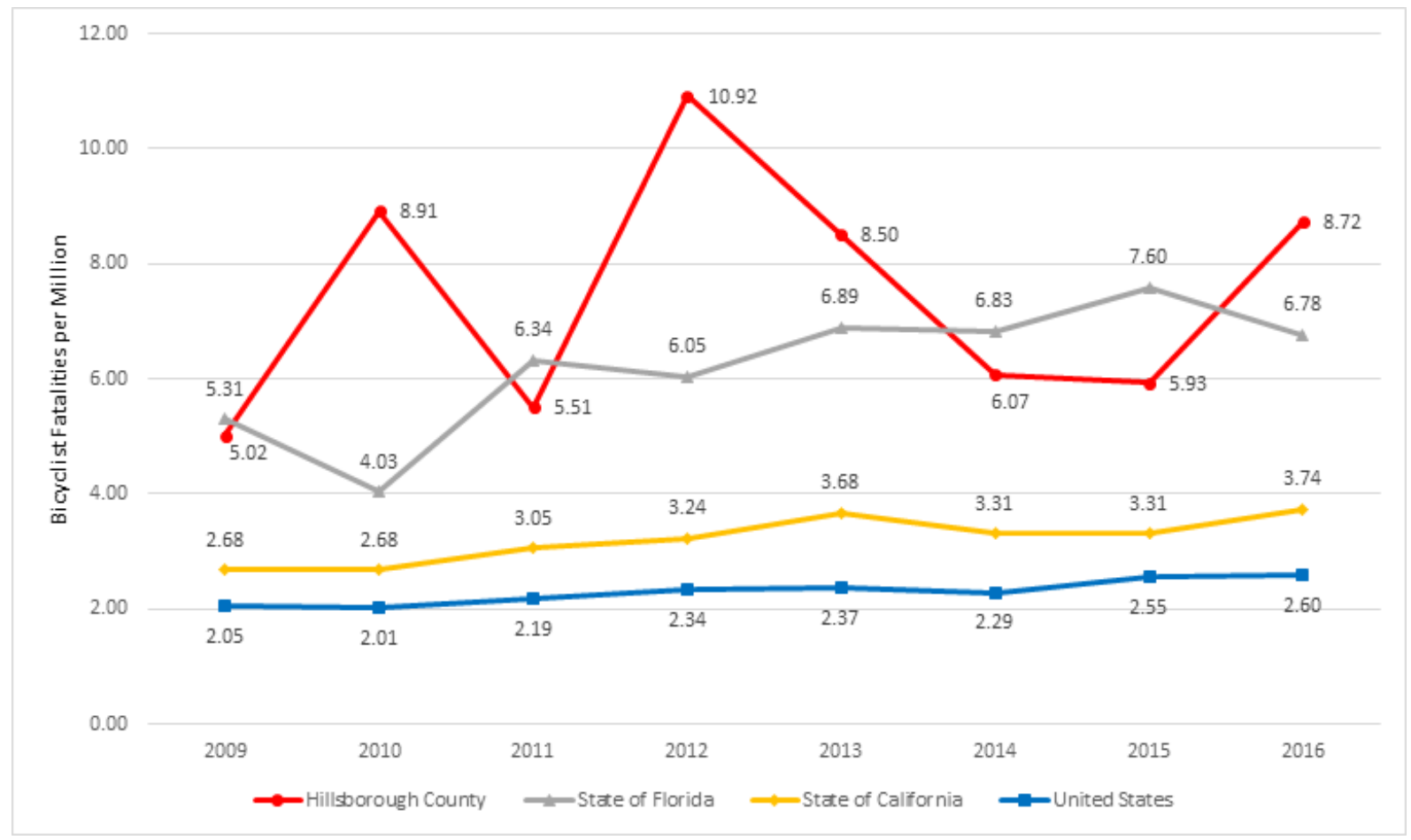

FIGURE 1. Bicyclist fatality rates per million residents for Hillsborough County, Florida, California, and the United States.

The high rate of fatalities makes Hillsborough County an appropriate site for transportation inquiry, which has the potential to provide insight into bicyclist fatalities and potential countermeasures statewide and nationwide. While pedestrian fatalities in the county follow a similar trend and represent a higher percentage of traffic-related deaths, this study focuses on bicyclist deaths as a primary exploration of transportation safety. In Hillsborough County, bicyclist fatalities were frequently reported by the media, yielding a comprehensive dataset through which to begin research about deadly traffic crashes. Though pedestrian deaths are more common in Hillsborough County, pedestrians are completely exposed vulnerable road users (VRUs) traveling with nothing but their bodies, while bicycles are considered legal vehicles: 
A bicycle is defined as a vehicle [§316.003(3)] for purposes of the Uniform Traffic Control Law...A person in control of a vehicle on a street or highway is a driver [§316.003(19)]. As a driver, a cyclist must follow the traffic rules common to all drivers. As the driver of a bicycle, you must also obey rules developed specifically for bicycles (Florida Bicycle Association, 2017, p. 5).

The differences between these two types of VRUs is significant because a bicycle is legally defined as a vehicle for travel, and the human body is a natural vehicle for travel, though its definitions are far more arbitrary and complex than those of a bicycle, which is an inanimate object that exists apart from the body. Though the material difference between bicyclists and pedestrians is concrete and defined objectively, the process of meaning making constitutes a philosophical difference that is symbolic and defined linguistically; these differences create opportunities for future lines of transportation inquiry that may be pursued to compare the language used to frame pedestrian deaths to the language used to frame the deaths of bicyclists. For the purposes of this study, the dataset (consisting of all bicyclist fatalities reported by written news media in Hillsborough County from 2009 to 2018) was chosen not only for its specificity and comprehensive qualities, but for its depth and breadth.

News media have recently (over the past ten years) focused more prominently on bicyclist and pedestrian safety in Florida, and newspaper reporting on bicyclist fatalities has contributed to public awareness of "the notoriously dangerous streets of Tampa Bay” (Morales \& Valentine, 2010). The high number of fatalities in the area have caught the attention of both media outlets and local transportation leadership, and policy makers and advocates have begun to discuss what it might take to make the streets of Hillsborough County safe for everyone. 
According to the 2015 Florida Transportation Trends and Conditions report published by the Florida Department of Transportation (FDOT), Florida's population grew by over 293,000 residents in 2014. Florida's efforts to improve both pedestrian and bicyclist safety have increased dramatically in less than a decade. However, as the state population continues to grow and the county develops at a rapid pace, neither population growth nor tourism explain the consistency of bicyclist fatalities in Hillsborough, as demonstrated in Figure 2.

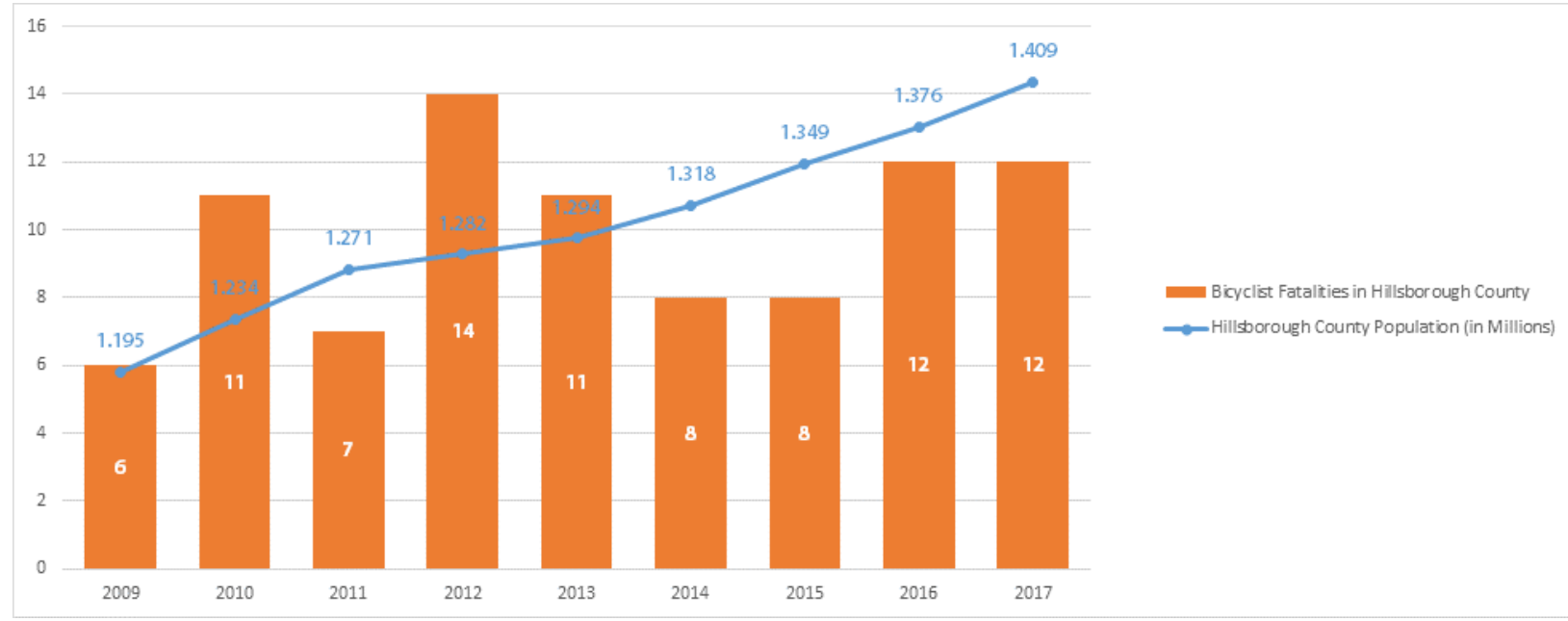

FIGURE 2. Bicyclist fatality rates per million residents and population growth over time.

For the purpose of this study, the research scope was limited to news reports of bicycle fatalities that occurred from January 2009 through June 2018 in Hillsborough County, Florida, where the risk associated with bicycling is high; it has been argued that people’s overall perception of road traffic risks typically draws on media reporting as well as their personal perceptions of risk in their everyday lives, demonstrating that media do influence public perceptions of risk (Hojman et al., 2005). Since 2009, 94 bicyclists died in crashes involving automobiles. Since the dataset represents Hillsborough County, the results of this study may not be generalizable to all of Florida but could be indicative of local urban and regional language practices in news reports about bicyclist fatalities. 


\section{LITERATURE REVIEW}

Recent research that examines news reports of bicyclist crashes in the United States includes Every Bicyclist Counts (2014). The dataset, though nationwide, was limited to bicyclist fatalities because most injuries are not reported by the news. The thematic analysis looked for trends in reporting:

In many instances the media reports take the perspective of the motorist in a motoristbicyclist crash, by explaining, for example, how a motorist failed to notice a bicyclist due to sun glare or dark clothing. Another theme included bicyclists crossing roadways and media reports failing to explain the circumstances of crossing by addressing which vehicle had the right of way and other factors, such as how much time the motorist had to react to the bicyclist's movement (2014, p. 8).

Other themes discussed in the report included passive voice obscuring the logistics of the collision, references to the bicyclists' equipment or attire without educating the public about what the law requires, discussing vehicles instead of persons, and a lack of follow-up reporting on charges faced or incurred by the motorist.

More recently, a study published in a Canadian journal entitled, "If you want to get away with murder, use your car: A discursive content analysis of pedestrian traffic fatalities in news headlines” (Magusin, 2017), discovered victim blaming content and context in an analysis of newspaper headlines reporting on bicyclist fatalities. The study focused on one year of bicyclist fatalities (there were 10) in Edmonton, the capital of the province of Alberta.

This research seeks to extend the 2014 report Every Bicyclist Counts as well as Magusin’s 2017 study. Instead of focusing on content analysis or thematic analysis (though content-related themes do occur), this research is a discourse analysis that works with a regional 
dataset: news reports of bicyclist fatalities in Hillsborough County, Florida, where a growing concern for bicyclist safety has catalyzed actions to eliminate traffic deaths at the local level. Transportation agencies, including the Florida Department of Transportation, have prioritized the development of "Complete Streets" in Hillsborough County:

Complete Streets are streets for everyone. They are designed and operated to enable safe access for all users, including pedestrians, bicyclists, motorists and transit riders of all ages and abilities. Complete Streets make it easy to cross the street, walk to shops, and bicycle to work. They allow buses to run on time and make it safe for people to walk to and from train stations (Smart Growth America, 2018).

In 2017, the Hillsborough Metropolitan Planning Organization (MPO), Plan Hillsborough, adopted a Vision Zero action plan with the goal of eliminating traffic deaths, especially for vulnerable road users (Plan Hillsborough, 2018). In many ways, the Hillsborough and Tampa Bay Area have begun to focus on safety for pedestrians and bicyclists, from education via Vision Zero to engineering and planning via Complete Streets. Although these are components that are necessary to improve bicyclist safety, the number of bicyclist deaths in Hillsborough County per year remains steady. This research approaches fatalities in a different way, by examining news reports of fatal bicycle crashes; media influences public opinion, which influences engineering and planning as well as the health outcomes of those activities.

\section{Framing}

In 1974, Goffman was one of the first scholars to introduce the concept of framing in the general sense. Frames, according to Goffman, help in turning events or situations that would otherwise be meaningless into a meaningful succession of events (Borah, 2011). Gitlin (1980) defined frames as the way in which journalists create large amounts of information into an 
organized set of information to be interpreted effectively by the audience (Borah, 2011). Entman believed framing involved salience and selection, taking components of a perceived reality and making them more salient through the communication of text in order for a problem to allow for causal interpretation or evaluation (Borah, 2011).

Framing effects occur when subtle changes in the presentation of an issue or event causes large changes of opinion (Chong \& Druckman, 2007). Those in the field of public opinion research found these effects when framing the questions of whether or not participants would oppose or favor a hate group to hold a political rally. Differences in the number of respondents who answered in favor occurred when the question was prefaced with "Given the importance of free speech,” yielding 85\%, while only $45 \%$ were in favor when the question began with “Given the risk of violence.” From this, researchers have concluded that among many other issues, phrasing the same issue alternatively can significantly alter the meaning to its audience, even when the change in wording is not automatically apparent (Chong \& Druckman, 2007). These framing effects have the potential to change the public's basic understanding of the issue at hand; however, how these effects have occurred are still poorly understood.

In 2001, Druckman introduced the emphasis approach to framing, which demonstrates that highlighting certain aspects in the message can lead to an influence on individuals to focus on these aspects (Borah, 2011). Due to this, individuals are led to concentrate on these aspects while interpreting them and making decisions about them. Scholars have further differentiated frames within emphasis framing, such as Iyengar's distinction of episodic and thematic framing (Iyengar, 1987).

Iyengar identifies framing effects as subtle changes stemming from alterations of judgment or choice problems. This concept was depicted in a number of studies which 
demonstrated that an appeal to different points of reference elicits completely different strategies of judgments. Iyengar's framing effects of news coverage describes two kinds of framing, episodic and thematic framing (1991). Episodic framing organizes news reported in the form of specific events or particular cases in concrete instances. Thematic framing, on the other hand, organizes news that accentuates political issues and events in some general context, reflecting collective evidence. Thematic frames point to larger structural and cultural issues instead of focusing solely on individual cases, lists of facts associated with those cases, and/or legal and personal responsibility. It is important to note that thematic frames tend to overlap with episodic frames because the general public responds to concrete events more readily than they do to abstract ideas, concepts, or issues (Iyengar, 1991).

In examining the effects of television news framing of political issues, results indicated that episodic framing tends to invoke individual rather than societal attributions of responsibility while thematic framing invokes the opposite (Iyengar, 1991). Iyengar posits that according to the way television news frames national issues, individuals' interpretations of these issues can be altered. In examining the issues of poverty, unemployment, and terrorism in this context, participants viewed a videotape showing news stories which exemplified these issues over the past six months. Results found that individuals relied on contextual cues to reason about these national issues. When media portrayed the presentation of issues around poverty, individuals' attributions of poverty (i.e., whose responsibility is it?) depended on whether news reported on particular victims of poverty (episodic) or focused on nationwide problems and outcomes (thematic) (Iyengar, 1991).

Alternatively, Norman Fairclough considers framing a perceptual communication phenomenon that occurs in cultural contexts, which can only be defined by linguistic structures 
and cues (1989). According to Fairclough, frames can represent types of people (e.g., bicyclists), inanimate objects (e.g., vehicles), processes (e.g., dying), or abstract concepts (e.g., economy). What is most important to discourse analysts is that frames are invoked by features of language, that language does something; it constitutes systems of meaning that regulate human behaviors and environments. For instance, newspapers are regulated by the assumption that news is based on objective fact and is free of bias and subjective inference. Fairclough argues that this assumption is flawed and that it bolsters the power of news media to define what is true.

\section{Hidden Power and "The News"}

First, framing news as something that generates "reports” suggests that news should do little more than provide the basic facts of an occurrence. However, as we have established through the results of this study and the discussion of those results, these reports are more complex phenomena that have the power to shape public opinion in ways that are not entirely factual or intentional. Reports about bicyclists' deaths on Hillsborough County roads that are episodic rather than thematic in their framing (Iyengar, 1991) are part of a communal discourse that, for analysts, bring about questions of truth, because news creation and consumption are interpretive processes.

According to Fairclough, newspapers possess "hidden power," which is easily tapped through the naturalization of institutional practices, practices which embody assumptions that either directly or indirectly legitimize existing power structures. In essence, universal or “common sense” practices are practices which only appear to be "common sense," but when discourse is examined closely, it becomes obvious that these assumptions are arbitrary and function to sustain unequal power relationships (Fairclough, 1989), power relationships made salient in the results of this study. The results are derived from a corpus analysis of episodic 
news reports wherein motorists and their vehicles are directly involved in the deaths of bicyclists. The vocabulary used to describe the event that led to a person's death, the absence of agency on the part of the motorist, the agency that is often attributed to the vehicle in place of the motorist, and the agency that is attributed to poor choices made by the bicyclist makes these events appear natural and dependent upon the activity of the bicyclist; the motorist is most often passive.

Fairclough argues that written language has a particularly nuanced quality, as it is onesided communication and communicators are generally separated by time and space when engaging with written texts (1989). And, because media communicate to mass audiences, producers of media texts cannot know the audience or adapt to it, and therefore they write to an ideal subject. This alone is a form of control over discourse, as readers of texts must negotiate an ascribed identity of the ideal subject in order to understand the article or text (which is often taken at face value). This raises questions of whose perspective is adopted in news reports, though those reports are often considered "factual," categorical truths.

Fairclough writes, "It is a form of the power to constrain content, to favour certain interpretations and 'wordings' of events, while excluding others” (Fairclough, 1989, p. 52). Fairclough claims that discourse is a site of ideological social struggle. Therefore, when examining and interpreting texts, we must note that both the production of a text and the interpretation of a text both have an interpretive character if we are to illuminate, understand, and transform these struggles and the positions of the parties involved. The producer of the text constructs the text as an interpretation of the world, or of the facets of the world which are then in focus; formal features of the text are traces of that interpretation (vocabulary, grammar, etc.). The traces constitute cues for the text interpreter, who draws upon her assumptions and 
expectations (incorporated in frames) to construct her interpretation of the text. Thus text interpretation is the interpretation of an interpretation (1989, p. 80).

Interestingly, the ideological burden is often on the reader, as they must call upon contentious, struggle-ridden assumptions as they interpret texts if they are to make sense of them. This is not to suggest that producers of texts embed these assumptions deviously - it is quite the opposite; usually, neither producers nor interpreters of texts are aware of the "common sense" assumptions that are evoked through discourse.

This study of discourse does not call upon those in power or demonize particular members of society; instead, it points to the power itself as it hides in language practices. Of course, power is not a "thing," but rather an abstract concept that is operationalized by language; the consequences of power can only be transferred to the concrete world through language that structures our assumptions about the nature of that world. This removes blame rhetoric from discourse analysis and allows for a creative but detached conversation to emerge about the empirical nature of language and its power.

Fairclough argues that language defines the social order within which predetermined social identities and power structures are born, reborn, and maintained (1989). The following section examines the social identities of bicyclists, which are signaled by the vehicle the bicyclist has chosen to operate as a mode of transport. When a person is observed operating a bicycle, their identity becomes bound to their chosen vehicle as this is the most efficient way to categorize people on the roadway. 


\section{Bicyclist Identities}

Identity, as Fairclough (1989) writes, is a kind of frame. Therefore, the way identities are assigned to bicyclists is a focus of this research. It is important to understand how these identities have evolved in meaning by examining the historical context of being a "bicyclist." The bicycle made its way to America in 1879 and quickly became subject to legal, religious, and medical controversy, making the identity marker of "bicyclist" a complex and politically contested communication phenomenon in light of its history. Disputes over bicyclists’ right to ride in the road erupted immediately when men took to the streets on two wheels in droves; they were considered “wheelmen,” but women were not far behind them (Aronson, 1951). In fact, it was the bicycle that liberated women from burdensome attire and allowed them to bare their ankles. When women took to the bicycle, they required freedom of movement, as "skirts, while they have not hindered women from climbing to the topmost branches of higher education, may prove fatal in down-hill coasting” (Aronson, 1951, p. 307). And it was the bicycle that led to the invention of bloomers, which were comparable to men’s knickerbockers.

However, most significant was the bicycle’s role as a primary mode of transportation for suffragists. Controversy over women's rights was ablaze when the bicycle came to America, as women fought for equality and the right to vote alongside men. The bicycle was a critical instrument to the suffragist movement, and its referent conjures images of Susan B. Anthony riding around to raise women and advocate for women's rights. Anthony was famously quoted in saying, "Let me tell you what I think of bicycling. I think it has done more to emancipate women than anything else in the world. It gives women a feeling of freedom and self-reliance. I stand and rejoice every time I see a woman ride by on a wheel...the picture of free, untrammeled womanhood.” It is arguable that the bicycle is what women rode to win the right to vote. 
This is a history that is seldom invoked in modern understandings of the bicyclist identity. When combined with other identity markers like gender and age, bicyclist identities may become more or less stigmatized (Aldred, 2013). For example, men and women often experience different types of harassment while bicycling. These differences reflect divergent power dynamics associated with bicyclists' gender identities that come into play within the physical context of the roadway. For instance, young men who ride bicycles for the purpose of exercise have different perceived social identities than women or the elderly who use the bicycle as a form of transportation (Kline \& Pinch, 1996). In the UK, cycling is seen as a positive childhood activity but is simultaneously seen as related to negative discourse surrounding youth crime and parental irresponsibility (Daily Mail, 2010; Kingsley, 2010, as cited in Aldred, 2013). According to Aldred, assumptions about bicyclists and motorists in the UK are stigmatizing to bicyclists' identities as they are negotiated on the road:

Goffman (1963, p. 3) defines stigmatised people as possessing "an attribute that is deeply discrediting within a particular social interaction” (my emphasis). Here, the social interactions in question occur within motorised street space, structured by legal, infrastructural, cultural, and policy environments.

Unique to bicycling is the idea that it is simultaneously considered a sport, or sign of privilege, and a stigmatized activity, or sign of poverty. While cycling is often viewed as “healthy,” other categorizations view it as risky (Aldred, 2013). Aldred’s research explored how these conflicting perceptions combine to inform bicycling identities, along with the ongoing debate over modal shift, conflicts that arise in the meaning of bicycling as an activity, and the ways in which bicyclists are perceived. Negative connotations of cycling, such as it being a sign 
of poverty, are often seen in tension with positive connotations that associate bicycling with health and exercise, or view it as an athletic activity.

To further understand the contradictions embedded in bicyclists’ identities, Aldred conducted interviews with bicyclists to uncover attitudes towards bicycling and bicyclists (2013). Results were analyzed using thematic coding, and several themes arose. Despite most interviewees identifying experiences with bicycling and road danger, including near misses or being knocked off a bike, most of the narrative was dominated by positive views of bicycling. A theme emerged in which bicyclists were struggling with the dialectic of being perceived as either incompetent or too competent on the road (Aldred, 2013). Some interviewees said they deliberately dressed in clothing that would distinguish them as a bicyclist in order to garner respect while bicycling. Clothing can signify both culture and class; this may be related to social disapproval of cycling identities and how these may not affect everyone in the same way. For those who are "middle-class,” (roughly half of the sample from this study) the identity of a cyclist is less problematic because the stigma associated with poverty is unlikely to be a threat (Aldred, 2013).

Transportation identities are fundamental to the types of interactions that occur in street space and emerge in the different ways that road users are treated. Stigmatized processes of cyclists operate in this way, as seen in the views of being too competent a cyclist or not competent enough. Participants identified that they had a tendency to self-deprecate in fear of being a "bad" cyclist (i.e. not cycling with lights at night, ignoring the rules of the road, or being in cars’ way) while avoiding being seen as too competent or recognized and stigmatized (dissociation from attire that would lead them to be identified, such as reflective vests or helmets, or being viewed as not having the "proper” body of a cyclist). Interviewees most often expressed 
the driver's point of view during interviews (car ownership rates are higher than the national average here). Some spoke of being a “good cyclist” by getting out of drivers' way - even at the risk of hitting potholes or having close calls with pedestrians (Aldred, 2013). The cyclist identity is complex, existing in car-dominated spaces which represent hostile environments - not only physically but psychologically.

Bicyclist identities are a framing device through which bicyclists may be perceived as abnormal; this deviation from normalcy is what Goffman calls a stigmatizing characteristic or “character blemish” (Goffman, 1963). Upon its invention, the bicycle was problematized and considered an intrusion (Aronson, 1951). Women rode bicycles to fight for voting rights, while modern bicyclists fight for the right to be on the road as an "alternative mode" of transportation. The literature reviewed demonstrates the ways in which bicycles are considered problematic and are associated with problematic behaviors, that cyclists are by default considered "bad” (Aldred, 2013; Kline \& Pinch, 1996; Aronson, 1951). It is important that identity is understood here as a moral construction - a "thing” we embody that is perceived as either good or bad, right or wrong, valuable or worthless - therefore, the ways in which we carefully avow identity for ourselves and hastily ascribe identity to others are ethical considerations. This research asks us to consider what language does to the complex processes of identity construction, power relationships, and meaning-making when reading news articles about bicyclist fatalities.

\section{News Reports of Bicyclist Crashes}

There is a small but increasing amount of attention given to language practices commonly used in crash descriptions, and in some cases, news reports of bicyclist crashes (MacRitchie \& Seedat, 2008; Rissel, et al., 2010; League of American Bicyclists, 2014; Badger, 2015; Macmillan, Roberts, Woodcock, Aldred, \& Goodman, 2016). Macmillan et al. (2016) 
researched police and news reports of bicyclist fatalities in London and compared them to reports on motorcycle fatalities. The researchers discovered that as the popularity of cycling increased, the news coverage of bicyclist fatalities covered in local media skyrocketed. Media reports may discourage people from cycling in London because it is seemingly too dangerous. Research in Sydney and Melbourne Australia found that reporting on cycling was 47\% positive and 30\% negative, and that three quarters of negative reporting involved the death of a bicyclist (Rissel, Bonfiglioli, Emilsen \& Smith, 2010). Interestingly, the results also found that “cycling” was more often framed positively while “cyclists” were more commonly framed negatively. Both these studies shed empirical light on news representations of bicyclists, but report on causal or quantitative relationships between cyclists and news media.

In another study conducted in Australia, a total of 160 cyclist crashes were covered from 198 newspaper articles spanning 2010 to 2013, with 71 resulting in the death of the cyclist (Boufous, Aboss, \& Montgomery, 2016). Within 12 crashes which were reported more than once, six involved public figures and/or their families while the other half involved prolonged court cases. For over $70 \%$ of the reports, characteristics of the cyclist were mentioned, including age, gender, and instances of the crash (i.e., time of day or type of vehicle involved). The specific type of crash was only identified in about $52 \%$ of the reports, identifying the road user at fault in 55\% of the reports. Conversely, key factors which may have contributed to the crash were mentioned in less than $13 \%$ of the reports: helmet use, alcohol involvement, speed, and the presence of bicycle lanes. Fewer than one in five crashes involved a discussion of proposed countermeasures. When these were mentioned they included educating motorists on sharing the road, changing infrastructure, legislation, and penalties for both cyclists and motorists. 
The fatalities reported by Boufous, Aboss, and Montgomery (2016) represented a little less than half of all bicycle crash reports (while the better half were non-fatal), exemplifying the suggestion that news media tend to focus on dramatic events (Boufous et al., 2016). If bicyclist deaths are extraordinary, the idea that countermeasures should be taken seems superfluous. This is evidenced by the researchers' discovery that the opportunity to propose preventative strategies and ignite public debate was only chosen or available to journalists in $20 \%$ of the reports (Boufous et al., 2016).

In sum, the literature reviewed demonstrate that studying language as a source of important data is a relatively new focus in transportation research. Understanding how language works as a framing device becomes increasingly important in widespread publications like "the news,” as transportation advocates attempt to develop lifesaving countermeasures. The main objective of this research is to understand the ways bicyclists are portrayed by common language practices. Things we take for granted, like grammar and vocabulary, have the potential to skew identities and deprioritize safety for people who ride bicycles. This is why discourse analysis is the appropriate way to question the role of media in disseminating information about transportation safety with regard to bicyclists. The focus is on language and the rules and definitions that come with it, not on the people who use it. In the end, the goal is to generate a dialogue about habitual modes of communication; only then can we create blame-free spaces to discuss the consequences and opportunities that come with them. 


\section{METHOD}

A 2015 article in The Washington Post addresses the common use of the word "accident" to describe traffic crashes: “An 'accident' is, by definition, unintentional,” writes Emily Badger in the first line of the article entitled, “When a car 'crash' isn't an 'accident' - and why the difference matters.” The article describes the call-to-action of an advocacy organization called Transportation Alternatives. In the summer of 2015, the organization launched a campaign asking people to pledge to stop calling crashes accidents: "Language, they believe, shapes policy. The word "accident," they say, presupposes a conclusion that no one bears responsibility" (Badger, 2015, para. 4). In fact, the Associated Press changed its guidelines in 2016 to advise journalists to avoid the term (AP, 2016).

Discourse analysts agree that language shapes policy - the meta-theoretical assumption of discourse analysis is that reality is more than one environment or another and the objects and subjects within it. Instead, DA begins with the assumption that environments, objects, and subjects both produce and are produced by conversation - that reality and discourse are inextricably linked. Negotiating reality is a process of questioning language practices and problematizing the taken-for-granted nature of language (Bartesaghi \& Castor, 2009).

Relationships with others and the institutions that enable, constrain, and influence human behavior are perpetually defined and re-defined by language practices. Discourses are language practices that construct a coherent system of meanings, refer to other discourses, reflect their own way of speaking, are historically located, reproduce power relations, and have ideological effects (Parker, 1992). As such, DA provides an interpretive meta-theoretical framework and a rigorous research method by which to examine language patterns in local news reports. DA looks at language closely to see how it functions at the micro-level. However, DA does not examine 
the intent of social actors or groups (e.g., bicyclists, motorists, police officers, lawyers, journalists, etc.) in order to move past conversations about personal blame and fault (conversations best left to legal debate) and work toward productive solution-oriented dialogue.

Discourse analysts look at how language works and attempt to apprehend what it does by looking only at the data of conversation or texts, and not reaching beyond what is already there not looking past the taken-for-granted. The Washington Post article that differentiated the word “accident” from the word “crash” sparked heated controversy on the website’s comments section. Some commenters argued that the use of the word "accident" was no different from the use of the word "crash" and that microscopic language choices such as these do not impact reality. Ironically, the passionate controversy they engaged in with other commenters about this particular language choice suggests that it is indeed significant. The purpose of this project is to critique common modes of discourse, making critical discourse analysis an appropriate tool in the process of understanding the ways in which bicycle fatalities are represented by news media.

\section{Critical Discourse Analysis}

Critical discourse analysis (CDA) is the method by which this project seeks to expose the subtleties of language and its function in relation to social structures and discursive events (Mele \& Bello, 2007). CDA is aimed at understanding and analyzing social inequities that are manifested and perpetuated by language use. An objective of CDA is to reveal dominance between social groups and to expose the formation of power and how language shapes the consent of dominance between these groups. Within this kind of analysis, researchers are able to draw attention to oppression that is inherent in cultural assumptions, and unmask social practices that perpetuate social problems. In the view of the critical analyst, language in the form of text is more than reporting facts or expressing feelings - it is a dynamic phenomenon that is inscribed 
with socially conditioned emotions and the motivation to achieve certain goals (Mele \& Bello, 2007). The use of language by individuals and its analysis reveal clues about the attitudes and beliefs of the text producer towards certain subjects, despite efforts made to try to conceal them. Fairclough (1989) considers "language a form of social practice” and contests that, via close analysis, linguistic devices are more than functions of grammar, style, and composition.

Henceforth, we call upon the nuances of language that shape meaning, which are typically taken-for-granted and naturalized so that they are treated as common, acceptable, and/or insignificant features of discourse. In order to explore the interests of who is being served by linguistic representations of reality, CDA is able to uncover hidden sociopsychological elements in written texts in order to generate different perspectives (Mele \& Bello, 2007). Language can be used to manipulate versions of reality, a discreet brand of manipulation that is germane to powerful sociological forces - forces that shape the experiences of those with more ideological authority, and those with less. CDA is used to determine the ways in which meanings are negotiated or imposed in order to expose what others are willing or able to see.

Social constructionism is the metatheoretical perspective that informs CDA methodology in its attempt to reveal taken-for-granted ways of relating to and understanding the world (Stjernborg, 2014). Through its examination of power relations, stereotypes, and norms, CDA explores how language is the key medium for the production of hegemonic discourses. Stjernborg (2014) used CDA of newspaper articles to analyze the negative images and discourses of the residents of a Swedish neighborhood by the daily newspaper and what effects the discourses have on constructing fear of mobility. The rationale for using critical discourse analysis of newspaper articles served several purposes for the study. One benefit was allowing the neighborhood to get its name out and situate the case within a wider context. Another goal 
was to illuminate the problems plagued by the neighborhood with the construction of mainly negative discourses in the media.

\section{Procedure of CDA}

In his 1989 seminal work, “Language and Power,” Normal Fairclough describes his procedure for critical discourse analysis. The procedure begins with description; the text is first examined for formulaic features like grammar, vocabulary, and other textual structures (for instance, the structure of a typical news report). Once the description phase is complete, the text is then interpreted and explained based on the description of the data. In part, Fairclough organizes the procedure with a series of questions that can be asked of a text during analysis: 1 . “What classification schemes are drawn upon?” 2. “Are there words which are ideologically contested?” 3. "Is there rewording or overwording?” and 4. "What ideologically significant meaning relations (synonymy, antonymy)” are there between words? (e.g., (Fairclough, 1989, p. 111).

In addition to vocabulary, grammar is of interest to critical discourse analysts. When examining texts for grammar, experiential values relevant to this study raise the following questions: 1. "Is agency clear?” 2. “Are processes what they seem?” 3. “Are sentences active or passive?” 4. “Are nominalizations used?” (p. 111). To determine the answers to these questions, the analyst must look at what grammar does to shape meaning. In the results section, the importance of each of these questions will be illuminated by describing the formal features of the text and what those features do.

Interpretation. Fairclough stresses the essential similarity between the discourse participants, or average readers of texts, and the analyst (1989). This is because producers of texts, readers of texts, and discourse analysts are all operating under shared common-sense 
assumptions about language and meaning that are embedded in cultural contexts. Fairclough defines these shared assumptions with the term "members' resources" (MR) and explains them with clarity in the following excerpt:

How is the analyst to gain access to the discourse processes of production and interpretation? These processes take place in people's heads, and it is therefore not possible to observe them as one might observe processes in the physical world. The only access that the analyst has to them is in fact through her capacity to herself engage in the discourse processes she is investigating. In other words, the analyst must draw upon her own MR (interpretive procedures) in order to explain how participants draw upon theirs. The analysis of discourse processes is necessarily and 'insider's' or a 'member's' taskwhich is why I have called the resources drawn upon by both participant and analyst members ‘member’s resources' (MR) (p. 167).

MR are interpretive procedures, which will be further illuminated in this section as six major domains of interpretation.

Social order. Social order is evident in institutional settings that interact with discourse participants' MR. In the process of interpretation, members draw upon the meaning of institutional settings to frame the situations they interpret, defining situational contexts. In other words, members understand the situation in the context of existing social institutions that create order. For instance, drivers of various vehicles are given different categorical locations within the social order, as drivers of larger and more powerful vehicles are expected to be on the road and to travel at high speeds. In the interpretation of a text about a fatal crash between a driver of a car and a driver of a bicycle, the institutional setting calls upon the assumption that the driver of the car belongs on the roadway and the bicyclist does not. 
Interactional history. Interactional history is a members' resource (MR) called upon when one text relates to other texts that address similar topics, which Fairclough terms “intertextual context."

Participants in any discourse operate on the basis of assumptions about which previous (series of) discourses the current one is connected to, and their assumptions determine what can be taken as given in the sense of part of common experience, what can be alluded to, disagreed with, and so on (1989, p. 145).

Thus, in the process of interpretation, one may take into consideration the history of the vehicle in the American economy, the capitalistic fruits and teachings of the Industrial Revolution, and the values and ideological leanings evoked by this shared history.

Grammar and vocabulary. The description stage is based on the identification of textual features that have predetermined meanings as a result of the rules of the English language. Vocabulary used in texts is also an element of description that identifies recurring word selections. Interpretation goes beyond the description of the sentence structure to interpret what that structure (vocabulary, grammar) does as it calls upon MR.

Schemata. Fairclough breaks schemata into three categories: schema, frame, and script. A schema is a type of activity "in terms of predictable elements in a predictable sequence” (p. 158). For instance, a newspaper report about a bicyclist fatality is predictably made up of content that tends to cover some combination of the 5 W's of journalism (who, what, when, where, why).

A frame also concerns the contents of a text in terms of its topic, as Iyengar suggests when classifying frames as episodic or thematic (1991). According to Fairclough, a frame is a representation of a topic or subject matter within an activity. Frames can represent types of 
people (e.g., bicyclists), inanimate objects (e.g., vehicles), processes (e.g., dying), or abstract concepts (e.g., economy).

"While frames represent the entities which can be evoked or referred in the activities represented by schemata, scripts represent the subjects who are involved in these activities, and their relationships,” writes Fairclough (p. 159). For instance, a police officer has a particular script she follows when responding to a traffic crash, and that script defines the relationship between the officer and civilians who are involved in the crash.

Explanation. The explanation stage examines processes of social struggle and structures of social power and control. Power relationships are the outcome of social struggles and are established and naturalized by those in power, putting emphasis on the results of past struggles. Conversely, discourses are part of social struggles and can be contextualized by non-discoursal social institutions (e.g., existing infrastructure). While description and interpretation take up matters of the production of texts, explanation is concerned with the reproduction of the MR that discourse participants draw upon in the process of interpretation. "This puts an emphasis on the social effects of discourse, on creativity, and on the future,” writes Fairclough (p. 153).

The results section that follows provides examples from news articles about bicyclist fatalities in Hillsborough County to elucidate the functions of discourse in producing and reproducing cultural meanings of multi-modal transportation at local and institutional levels. Fairclough's procedure for critical discourse analysis is put to use in describing, interpreting, and explaining the nuances present in the episodically framed texts to uncover patterns indicative of the social effects of the discourse. 


\section{Data Collection}

The dataset for this study consists of 190 news reports of 94 bicyclist fatalities that occurred from January 2009 through June 2018 in Hillsborough County, Florida, to create a complete dataset of all fatalities within this timeframe. To create a comprehensive dataset, the researcher first consulted Florida’s Integrated Report Exchange System (FIRES) to document the number of reported bicyclist fatalities. Next, the names of the bicyclists, and the date and locations where the deaths occurred were compiled using internet searches and a public list compiled by a local safety advocate. Finally, data was verified using the Florida Department of Transportation District Seven’s Crash Data Management System (CDMS). The information collected was used to filter the results on a database inquiry of local news sources that reported on the incidents, including the Tampa Bay Times, the Tampa Tribune, the St. Petersburg Times, WSTP 10 News, Bay News 9, Fox 13 Tampa Bay, WUSF Public Media, ABC Action News, and other news outlets appearing in print and online.

The search terms used were: (bike OR bicycle OR bicyclist OR crash OR collision OR struck OR killed OR dead OR death OR dies OR died OR fatal OR fatality OR accident) AND Tampa or Hillsborough County AND (“Name of Bicyclist”). The results were filtered by the month and year of each death. All published stories were collected, excluding data from blogs or non-official news sources (e.g., lawyers’ websites reproducing news as advertisement for their services). Search results were thoroughly examined, and data were cleaned, checked, and crosschecked to ensure accuracy. Stories were converted to a .pdf file format and imported into a qualitative data analysis software. All news reports referenced in this research are in the public domain. 


\section{Data Coding and Analysis}

Fairclough's method of discourse analysis (outlined in the above literature) was used for coding the data. Coding categories, or “nodes,” were created based on Fairclough’s general categories of “experiential” and "expressive” codes. Experiential codes were identified during the description process (vocabulary, words/wording, classifications, grammar, and sentence structure). Expressive codes were also identified during analysis and interpretation; these are later explained in the results section along with the experiential codes. Expressive codes denote features embedded in the content of a text, particularly related to the ways in which content evaluates subjects, identities, and outcomes. Based on this organization, general parent and child nodes were identified to begin the coding process.

First, a process of open coding was employed using qualitative analysis software to generate queries based on the general nodes. For example, queries were run for particular terms like “crash” and "accident,” a process that assisted the researchers in describing the data. All query results were saved and the articles they returned were assigned to the corresponding nodes.

Then, selective coding was employed to mark textual features and language patterns according to Fairclough’s procedure. Each article was coded manually and data within each article were assigned to general nodes. During this process, the researchers made note of emerging patterns in the text and identified new categories and subcategories of nodes, which were added to the scheme of coding categories. The process was repeated in a second round of coding.

When the coding was finished, the nodes were refined by combining repetitive nodes and revising the organization of parent and child notes. To ensure coding accuracy, double-coding 
was performed, returning a Kappa value of 0.8, reflecting intercoder reliability. Table 1

represents the final organization of nodes:

TABLE 1. Experiential and Expressive Nodes

\begin{tabular}{|c|c|c|c|c|c|}
\hline \multicolumn{6}{|c|}{ EXPERIENTIAL NODES } \\
\hline \multicolumn{6}{|c|}{ CLASSIFICATION/VOCABULARY } \\
\hline \multicolumn{2}{|c|}{ Bicyclist } & \multicolumn{2}{|c|}{ Event } & \multicolumn{2}{|c|}{ Motorist } \\
\hline "Bicyclist" & "Person" & "Accident" & "Hit and Run" & "Car" & Specific Make \\
\hline "Boy" & "Teenager" & "Collision" & "Incident" & "Driver" & "Teenager" \\
\hline "Child" & Specific Name & "Crash" & "Killed" & "Man" & "Truck" \\
\hline "Girl" & "Victim" & "Death" & "Struck" & "Motorist" & "Vehicle" \\
\hline "Kid" & "Woman" & "Fatality" & "Wreck" & "Person" & "Woman" \\
\hline "Man" & & "Hit" & & Specific Name & \\
\hline \multicolumn{6}{|c|}{ GRAMMAR } \\
\hline \multicolumn{2}{|c|}{ Agency } & \multirow{3}{*}{\multicolumn{2}{|c|}{ Nominalizations }} & \multicolumn{2}{|c|}{ Passive Sentence Structure } \\
\hline Bicyclist Agency & Bicyclist No Agency & & & & \\
\hline Motorist Agency & Motorist No Agency & & & & \\
\hline \multicolumn{6}{|c|}{ EXPRESSIVE NODES } \\
\hline \multicolumn{6}{|c|}{ EPISODIC ARTICLES } \\
\hline \multicolumn{2}{|c|}{ General Outcomes } & \multicolumn{2}{|c|}{ Outcomes for Bicyclist } & \multicolumn{2}{|c|}{ Outcomes for Motorist } \\
\hline Effect on Traffic & Public Safety & $\begin{array}{l}\text { Charity } \\
\text { Memorials }\end{array}$ & Others' Grief & $\begin{array}{l}\text { Charges } \\
\text { Emotions }\end{array}$ & Injuries \\
\hline \multicolumn{2}{|c|}{ Safety } & \multicolumn{4}{|c|}{ Social Identity } \\
\hline \multirow{4}{*}{$\begin{array}{l}\text { Bicyclist Safety } \\
\text { General Safety }\end{array}$} & \multirow[t]{4}{*}{ Motorist Safety } & \multicolumn{2}{|c|}{ Bicyclist } & \multicolumn{2}{|c|}{ Motorist } \\
\hline & & Age & Gender & Age & Gender \\
\hline & & Class & No Pronoun & Class & No Pronoun \\
\hline & & \multicolumn{4}{|c|}{$\begin{array}{c}\text { THEMATIC ARTICLES } \\
\text { (Open Coding) }\end{array}$} \\
\hline
\end{tabular}

Finally, a process of axial coding was employed to identify recurring relationships between nodes. These were saved and provided the foundation for analysis of the data. Data analysis centered on the frequency of experiential nodes, which include the most commonly used terms and grammatical structures. The researchers also focused on the most common relationships between nodes and the framing of the articles.

De Beaugrande (1997), McEnery and Wilson (2001), and Stubbs (1996) call this form of discourse analysis “corpus analysis,” a form of detailed, labor-intensive analysis that is applied 
to large samples of data (more simply, “corpus” means “a collection”). Corpus analysis allows researchers to focus on a variety of textual features and supplement their interpretations with quantitative considerations, such as frequencies of keywords and distinctive patterns and relationships within a collection of texts.

Episodic frames were differentiated from thematic frames; episodic frames constituted the majority of the data, providing a formulaic body of news reports on bicyclist fatalities, while thematic frames provided contrast and context. The results of this study focus primarily on episodic frames, since they make use of language structures that reveal the cultural assumptions surrounding bicyclist fatalities. Thematic data were used during analysis to provide insight into language about transportation safety, and to make conclusions and provide suggestions for reform and future research. 


\section{RESULTS}

The results of this project focus on the ways in which bicyclist fatalities are portrayed in newspaper texts published about events that occurred over the course of a decade in Hillsborough County, Florida.

"All forms of fellowship, community and solidarity depend upon meanings which are shared and can be taken as given, and no form of social communication or interaction is conceivable without some such 'common ground,'” writes Fairclough (2003, p. 55). News stories are of narrative construction, and as all narratives go, news stories arrange events in some order that is not always factually chronological but maintains "common ground" with readers via common sense or taken-for-granted assumptions (Fairclough, 1989; 2003). For instance, most news stories about bicyclist fatalities begin with the end of the event that is described: a "bicyclist” is dead. From there, common sense assumptions are called upon (often unconsciously on part of both the author and the readership) and can be likened to the following journalistic ideals: the story is objective and fact-based and does not mean anything beyond what is presented in the account of what happened to cause the bicyclist's death.

Another narrative convention observed in news stories is that they portray social agents as characters in a story that originates from a particular point of view (Fairclough, 2003). In the case of most of the news stories collected as data for this project, the narrative of each bicyclist fatality is delivered in only a few brief paragraphs. This is what Iyengar (1991) calls "episodic framing," which functions to isolate the story and its characters from larger contexts and complexities that affect public perception. The episodic framing of these stories may encompass a variety of viewpoints but the viewpoint conveyed most is simple, clear, and requires no further thinking on the subject: these fatalities happen, and happen often. 
Almost no episodic articles in the dataset address the outcomes for the parties involved, larger causes of these events, or preventative safety measures. However, given the significant number of thematic articles (56 of 189) about bicyclist fatalities in the area, the minority of data suggest that they happen for reasons that can be prevented, and that the "epidemic" of bicyclist fatalities in Hillsborough County is undesirable for some of the more prominent social actors in the surrounding communities, particularly political figures and organizations, engineers, law enforcement, urban planners, and bicyclist advocacy groups.

The results the report focus on the episodic frame, as it is most common and contains the kind of data necessary for this method of analysis, including vocabulary, grammar, and linguistic patterns and relationships common to texts that report bicyclists' traffic deaths. As mentioned in the method section of this paper, software for qualitative data analysis was used to identify these textual features. The results include patterns and relationships with vocabulary use and frequency, grammatical meaning, the agency of social actors, the social identities of agents, and inclusions or exclusions of meaningful textual features.

\section{Taken-for-Granted Vocabulary}

Overall, the vocabulary used to describe fatal traffic events draw upon taken-for-granted, common-sense assumptions that motorists and bicyclists (the subjects) are fundamentally equal and therefore bear equal responsibility for traffic safety on the roadways. This presumed balance in power is emphasized with the words "accident" and "incident." These words are what linguists call "nominalizations," or verbs that have been transformed into nouns to abstract the action of the subjects. Nominalizations are often used in passive constructions of sentences in which there is no subject or the action is detached from the subject. This level of abstraction 
allows the reader of the news to habitually process the information based on "common sense" easily, without thinking critically about the content of the story.

Accident/Incident. The word "accident” was used to represent bicyclist fatalities 62 times in 48 articles. Through the literature review, the researchers presented the argument that the word "accident" removes blame from the motorist and suggests that the event was unavoidable. The word "incident” was used 13 times in 12 articles, which Merriam-Webster describes in more abstract terms as a noun that is synonymous with an event, occurrence, episode, or circumstance. This may leave out the assumption that the incident is unintentional or unavoidable, but does little to ground the event in ways that suggest the existence of context, or indicate the event's connection to a concrete and embodied reality.

Crash/Collision. The word "crash" was used 168 times in 91 articles, and the word "collision" was used 26 times in 22 articles. This means a vast majority of the news stories in the dataset use the word "crash" to describe traffic deaths that kill bicyclists. As presented in the literature review (Badger, 2015), the term “crash” is preferred among language activists because it is indicative of harm, though it still removes action from subjects.

\section{Grammar and Agency}

Agency is conscious action by a clear actor. It is communicated in language through grammatical structure. In almost all the news articles analyzed for this project, motorist agency was eliminated from the story through a variety of grammatical choices.

Passive sentences. A sentence is written in a passive construction when the subject is absent or included after the verb, as in "A bicyclist was killed by a car." In addition to nominalizations, passive constructions of sentences serve to remove agency by emphasizing the action rather than the actors. More than half of the articles in the sample used passive sentences 
when describing the traffic event. Often, the motorists were not included in the sentence as the agent, and when they were, they were often referred to as the vehicle instead of by name or any human identifier. In contrast, most of the active sentences in the articles were used in reference to the bicyclist, as in "The bicyclist was riding at the intersection of..."

Motorist agency. The main way that motorist agency was eliminated was to omit the motorist's name and/or obscure the presence of a driver and emphasize the activity of the motor vehicle the driver was operating. In 55 of 189 sources, the motorist was replaced at least once with the word "truck" (usually multiple times within a source), totaling 111 references to the vehicle as an agent in bicyclists' deaths. The following are examples of this:

When a bicyclist died Nov. 1 on Fowler Avenue, investigators said a pickup truck entered a triangular safety zone and collided with the bike.

Boger was standing with his bicycle on the corner of Waters Avenue and Florida Mining Boulevard at 2:14 p.m. when a Mack truck made a sharp right turn and hit Boger, deputies said.

When Campbell started to cross the road, her bicycle went into the path of the truck.

In addition to the 55 trucks that are given agency in the dataset, cars are also agents in 50 additional articles and the word "car" is referenced a total of 138 times:

Teen on bicycle killed after being hit by car in Apollo Beach: A 13-year-old riding a tricycle died Saturday (Aug. 12) night when hit by a car, the Hillsborough County Sheriff's Office said.

The sheriff's office reports that the first boy, 12-year-old Mitchell Bowers, died Tuesday evening. He had been riding in the bicycle lane when he reportedly turned left in front of a car and was hit.

Bryan Lebron Jr., 11, of South Tampa, died Wednesday afternoon after he was struck by a car at South Dale Mabry Highway and Bay Avenue.

The word "vehicle" is used in place of the motorist 103 times over 70 of the articles.

More common than replacing motorists with these generic terms is replacing them with the 
specific make and/or model of the vehicle, making the naming of the agent more specific. The make and model of the vehicle was the descriptor of the agent in 97 articles and was referenced a total of 106 times.

A 2002 Dodge truck approached from behind near Jana Drive, traveling about 45 mph. Police say Edward Nelson Lewis, 55, was struck by a Honda CRV on North Nebraska Avenue and East Emily Street just before 5 a.m.

Ivan Miller, 47 of Tampa was standing in the inside lane of U.S. Highway 41 south of 10th Street near the white painted line divider when he was struck by a 2012 Honda Civic at 7 p.m.

\section{Relationship between Bicyclist Class and Bicyclist Safety}

Besides using vocabulary that contains assumptions about responsibility and grammatical strategies that remove agency, the episodic articles revealed a relationship between bicyclist class and bicyclist safety.

There are various ways to indicate the approximate socioeconomic status of a bicyclist. A relationship exists between unsafe bicycling behaviors and lower-class identity markers, while an inverse relationship exists between safe bicycling behaviors and higher-class identity markers.

The first of the two examples to follow are indicative of the former relationship.

Weeks, riding against traffic, was on his way home from a landscaping job.

In this example, the bicyclist, Anthony Weeks, was riding against traffic, which is illegal and unsafe. In the same sentence, there is an association with his vocation, a landscaping job. This line of work is not considered a career, but a trade, and Anthony is identified as a laborer with little economic power.

Police said Gutierrez was riding north against a red light at Woodland Corporate Blvd., in front of the Waterford at Cypress Lakes apartment complex, where he lives.

Another way to mark the socioeconomic identity of a person is to describe their living conditions and/or the location of their homes, as the above sentence does in the case of Jose Baez 
Gutierrez. Conversely, when bicyclists are of a higher status, they are more often portrayed as having practiced safe behaviors at the time of their deaths, as in the case of Kayoko Ishizuka, a cancer researcher at the University of South Florida:

At the time of the crash, Ishizuka had lights on her bike, wore a helmet and rode in the bike lane, Coleman said.

Ishizuka was known as one of the "best and the brightest" in her field. She bicycled for the love of it, not out of necessity.

Rivera lost control and struck cyclist Robert Niedbalec, 52, a Temple Terrace veterinarian and black-belt instructor, who was riding in a designated bicycle lane.

In this example, Robert Niedbalec is identified as a cyclist, a veterinarian, and a black-

belt instructor who was riding his bike in the designated bike lane. This demonstrates his contribution to society and his choice to follow the law. However, it is not mentioned in any of the myriad articles about his case whether he wore a helmet when he was killed in the designated bike lane. In articles including identity markers that may suggest bicyclists are of lower socioeconomic status, it is often mentioned that they were not wearing helmets when they died, although it is not a violation of Florida law to ride without a helmet unless the bicyclist is underage.

\section{Opportunities in Thematic Framing}

A significant portion of the dataset are written with thematic frames (56 of 189), suggesting that bicyclist fatalities happen for reasons that can be prevented, and that the prevalence of bicyclist fatalities in Hillsborough County is undesirable for some of the more prominent social actors in the surrounding communities, particularly bicyclist advocacy groups, political figures and organizations, engineers, law enforcement, and urban planners. 
Thematic frames in the dataset highlighted issues associated with social capital, safety education, and bicycle advocacy.

Social capital. Networks of people come forth to grieve together, support one another, and, in the case of some bicyclists' deaths, plea for safer roads for bicyclists when a loved one dies. These people have social capital and their value is communicated in thematic reports, while this is not the case for most of the bicyclists in the data. In other words, some bicyclists were reported to be valuable assets in the networks to which they belonged and, as a result, their deaths were framed as tragic and senseless in opposition to episodic "hard news" stories. The following excerpts are expressions of emotional hardship that develop the meaning of the abstract concept of "public health" and help audiences to understand the implications of our current epidemic.

Bryan's mother said the family was close. The boys shared a bunk bed. Bryan had the top where a big stuffed green frog remains, along with an open book: 20,000 Leagues Under the Sea. Donté listed his brother's favorite things: basketball and the colors red, blue and black. What did he like most? "Me," Donté said.

Each Friday morning, at the exact minute her bicyclist sister Diane was hit and killed on a Tampa sidewalk, JoAnn Vega stands at the street corner and rings three cowbells. Her sister loved the Rays...Tuesdays, instead of meeting her daughter Diane for their onceweekly lunches, Amelia Vega visits the corner to tidy the memorial. She rearranges the candles and brings fresh flowers.

Both the above examples illustrate social capital via family networks and the deep-seated grief that is suffered by real people when bicyclists die and leave beloved kin behind. The following excerpts include family, professional, communal, and friendship networks.

Calonge's father opened Joe Haskins Bicycle Shop in Tampa in 1953. Diane Vega was a regular at the shop, chatting with the employees and asking that Haskins do the repairs. "She was more than just a customer," Calonge said.

"Dr. Niedbalec, by all accounts, was a wonderful man," Battles said. "To characterize this as anything less than absolutely senseless would be a mistake..." They were judo 
students, veterinary partners, friends, and his widow, Kathryn, and his daughter, Kate. They spoke of a man who loved people as much as he loved life.

A fifth-generation Floridian, Mr. Collins was the son of LeRoy Collins, who, as governor from 1955 to 1961, appealed to heads and hearts of average Floridians to reject racial segregation.

Social capital garners respect by adding value to the bicyclist through association with family, professional, communal, and friendship networks.

Safety Education. Most of the thematic articles focused in some way on safety education or bicycle advocacy. The following is an example of these articles' focus on pragmatic information about the rules and laws for safe cycling and sharing the road.

But also the need for riders and drivers to understand the rules of Florida roads. Under state law, bicycles are considered vehicles and have the same rights as motorists, said Tim Bustos, executive director of the Florida Bicycle Association.

The following example elaborates on the importance of visibility, and the responsibility and agency of the bicyclist is emphasized.

Bicycling safety advocate Alan Snel said motorists and bicyclists must learn to properly share the road. And bicyclists need reflective clothing and lights on both wheels when riding in the dark. "Light yourself up like a Christmas tree," Snel said.

Bicyclist advocates and local transportation leadership work to inform the public of cyclists' legal rights and garner political support for the protection of cyclists on Hillsborough County roads. For example, Gena Torres, a senior transportation planner in Hillsborough County, stresses the legal status of the bicycle as a vehicle deserving of its own infrastructure:

"The solution is not just to try and rid the roads of bicyclists and put them on a trail," she said. "A bicycle is a vehicle."

Bicycle Advocacy. Advocacy also takes the form of joining with international

movements, like the Ride of Silence, written about in the excerpts below:

The bikes are personal memorials honoring the dead, but they're also symbols, part of an international movement aimed at reminding motorists to watch out for bicyclists. 
Bicyclists are a common sight along the stretch of road. Bicycle safety advocates already were planning a 15-mile bike ride Friday to honor five bicyclists killed in about two months. They said people need to speak up to politicians about the need to improve bicycle safety. About 60 people attended the Honor the Fallen Bike Ride, which traveled into downtown Tampa and Ybor City before returning to Seminole Heights.

Advocacy and awareness are important elements of public health education that make the safety needs of cyclists known. However, the road systems available to cyclists also contribute to local safety concerns. Some of the news stories highlighted problems with local infrastructure that may have contributed to the fatal episodes reported in the articles. For instance, inadequate bicycle lanes that contain hazards are problematic, along with the absence of bicycle lanes in areas that need them.

Torres said part of the solution is to add more bike lanes and take steps to slow traffic in certain areas.

Bayshore Boulevard now has a dedicated bicycle lane, but many do not use it because of debris and fast cars that sometimes drift to the right.

Sheriff's officials noted that the accident happened in an area where there is no bike lane or paved shoulder. That particular stretch of Gunn Highway is narrow, as the road curves around Lake Calm.

The results indicate that thematic framing is an important device and has the potential to be instrumental in the reporting of bicyclist fatalities. In combination with an understanding of how textual features shape meaning and identity, a public reframing of bicyclist fatalities and the people who suffer them is a necessary countermeasure. This means understanding the ways in which language and perception work together to shape our beliefs about who is valued in society, and who is not. The following section offers a discussion of other insights and implications gleaned from the results, a formula for reframing bicyclist fatalities in news stories, and implications for future research. 


\section{DISCUSSION}

News reports, also referred to in this research and colloquially as "stories," are generally "of narrative construction, and as all narratives go, news stories arrange events in some order that is not always factually chronological but maintains 'common ground' with readers via common sense or taken-for-granted assumptions” (Fairclough, 1989; 2003). What this means is that as we read the news, we make narrative sense of it. There are characters (bicyclists, motorists, law enforcement, witnesses), and as Fairclough suggests, they portray social agents who are active in a story that originates from a particular point of view (2003).

As the results of this research indicate, the narrative of each bicyclist fatality is typically delivered in only one or two short paragraphs and originates from a third person point of view. The third person perspective is appropriate for this kind of storytelling; a reporter writes from outside the scene and from the perspective of a third party who responded to the scene of the fatality. Since episodic (Iyengar, 1991) stories are generally written with only one source (a police report), the officer who wrote the report (as required by the institution the employs the officer) is this third party.

Most fatalities make the news, but not all of them, as was true of the dataset utilized in this project. Boufous, Aboss, and Montgomery (2016) discovered that bicyclist fatalities were considered dramatic events and were reported on more frequently than other traffic-related stories. However, since Tampa has a higher fatality rate than most places, bicyclist deaths create a predicament of ordinariness. Ben Montgomery, Bike/Walk Tampa Bay board member, former reporter, and professor of journalism commented that this was a difficult issue for Tampa's area journalists to address because their job is to report on subjects of interest (personal communication, 2017). If bicyclist deaths or ordinary, then they are not newsworthy. But, if 
bicyclist deaths are extraordinary, the idea that countermeasures should be taken seems superfluous. The story of the dead bicyclist can be changed, as its current episodic nature lacks both extraordinary and ordinary qualities. If writers attempt to find balance between these opposing merits, the report may become more newsworthy and escape this either/or dichotomy. In other words, a balanced story might include relevant facts that reach beyond the episode and into the institutional structures that shape it (for instance, infrastructure, public safety education, etc.), while attending to the episode as a tragedy and showing readers the human thread that runs through it.

From here, the discussion covers three elements of the news story narrative by examining Fairclough's notions of schemata, social identities, and scripts. These three processes of human perception lend themselves well to repeated narratives (episodic frames of bicyclist fatalities) that shape taken-for-granted assumptions that produce and reproduce cultural landscapes.

\section{Schemata: The Hit-and-Run}

Schemata is plural for schema, which is an outlined way of thinking common to all people of a culture. Schemata are tools of perception, mental short-cuts that allow for humans to exercise the appropriate and efficient behaviors that are required for survival within a particular culture. Bonham links a culture of efficiency with modal choice (2006). She writes, "Certainly, transport behaviouralists have examined a range of factors which might influence the modal choices people make; however, transport experts continue to comprehend these factors within the framework of the efficient journey (p. 70)” However, a schematic focus on efficiency in transportation is lost in the hit-and-run story, prompting readers to instead consider the legal and ethical sanctions of a crime. The hit-and-run scenario calls upon a particular set of schemata that 
changes the narrative of the dead bicyclist quite dramatically. As illustrated below, hit-and-runs account for $22 \%$ of all bicyclist fatalities in the dataset.

\section{Hillsborough County Bicyclist Fatalitites: \\ Hit and Run

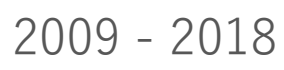

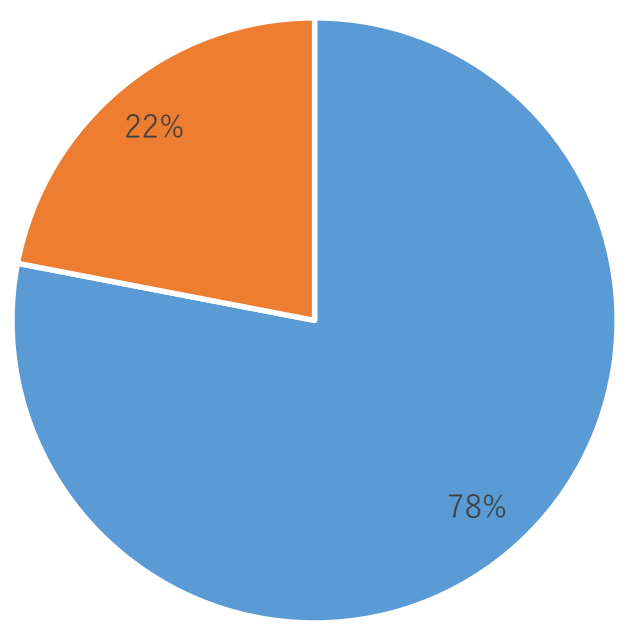

- No Hit and Run

- Hit and Run

\section{FIGURE 3. Hillsborough County Bicyclist Fatalities Reported as Hit-and-Runs.}

Agency and the hit-and-run. It is important to note that when a fatality is caused by a hit-and-run driver, the motorist has not yet been identified so the vehicle replaces the individual. Law enforcement is looking for the vehicle make, model, and its other potential identifiers in order to link it to a person who has committed a crime, and police are asking the public for help to solve the crime. Therefore, the hit-and-run prompts a different way of making meaning that calls upon a legal schema of crime and punishment. Someone has broken the law, and now readers are potential heroes who may be able to help the police to enforce it.

In 41 of the news reports, the phrase "hit-and-run" is used, and in many of those articles the driver is subsequently caught and identified. When a hit-and-run driver is caught, the agency 
of the driver dominates the data rather than the agency of the bicyclist. This phenomenon is somewhat natural within the context of the hit-and-run schema because the very foundation of the American justice system rests on the notion of personal responsibility. However, what is important to note is how quickly framing shifts when a different set of taken-for-granted assumptions is called upon; when no criminal activity is involved, responsibility is attributed to the dead bicyclist.

\section{Social Identities}

In the identity literature reviewed for this project (Aldred, 2013; Kline \& Pinch, 1996; Aronson, 1951) it is argued that bicyclist identities are often stigmatized (Goffman, 1963) and that there is a sort of moral questioning of the bicyclist's identity on the roadway. Using the word "bicyclist” to describe someone is a verbal marker of identity. [Nonverbal identity markers also exist but they are wordless; for instance, a person’s skin color is a marker of identity.] Other ways of identifying bicyclists in fatality reports are by age and sex, as each of these is also an identity marker (see figures below for details).

\section{Hillsborough County Bicycle Fatalities by Age of Bicyclist 2009 - 2018}

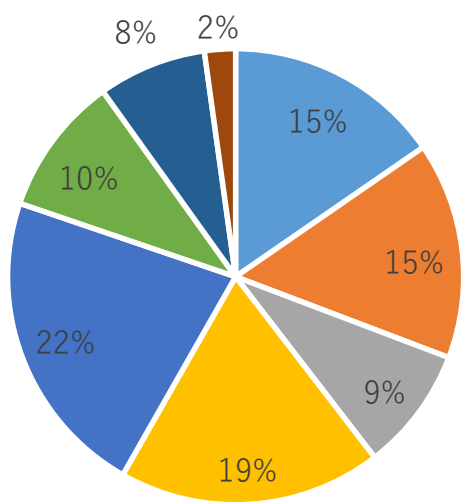

- 10 to 19

- 20 to 29

- 30 to 39

- 40 to 49

- 50 to 59

- 60 to 69

- 70 to 79

- 80 to 89

FIGURE 4. Hillsborough County Bicycle Fatalities by Age of Bicyclist 2009-2018. 


\section{Hillsborough County Bicyclist Fatalities by Sex of Bicyclist}

\section{$2009-2018$}

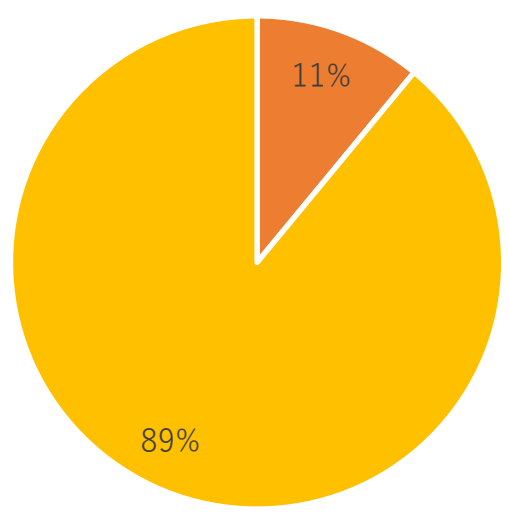

- Female

FIGURE 5. Hillsborough County Bicycle Fatalities by Sex of Bicyclist, 2009-2018.

Age. The data demonstrate that most bicyclist fatalities occur within the age group of 50 to 59 years (22\%), while a comparable $19 \%$ of bicyclists are 40 to 49 , making the majority of bicyclists in the data between 40 and 59 years old. Parallel to this is the fact that young people and children are also frequently lost in this same way, with $15 \%$ of fatalities occurring within the 10 - to 19 -year-old age group and another $15 \%$ within the 20 - to 29 -year-old age group. Age is an identity marker that may result in frames that emphasize tragedy and loss (thematic) or frames that emphasize facts and personal responsibility (episodic).

The bicyclist fatalities that befell children or teenagers punctuate the dataset with thematic articles that acknowledge the tragedy of the loss; for instance, the author mentions that young people who knew the deceased student will have access to grief counseling via the school. Less common are thematic articles about the older age groups (the majority), unless an age identity marker intersects with other identity markers. For example, identity markers that build social capital or value (affluence and/or standing within the community) like "veterinarian” and 
"father" were used to describe Robert Niedbalec. Niedbalec was 52 when he was killed by a teen who was drag racing and is part of the age group of 50- to 59-year-old bicyclists - generally a group featured in episodic articles or no articles at all. However, he was known in the community as a beloved family man and judo instructor (these labels are also identity markers), and the news about his death renders him complex and human.

In a Tampa Bay Times article by Silvestrini (2014), the judge sentencing the teen for his death is quoted: "Dr. Niedbalec, by all accounts, was a wonderful man. To characterize this as anything less than absolutely senseless would be a mistake, senseless with such horrific consequences” (para. 8). This article, along with the other six written about Niedbalec's death, goes far beyond the simple identity of a 50-year-old male bicyclist, which brings the discussion to sex.

Sex. Though communication scholars tend toward the word "gender," police reports do not, so the word sex will be used to reflect that fact. The statistics regarding the sex of the bicyclist are overwhelmingly skewed, as a vast majority of the fatalities happen to male bicyclists (a staggering 89\%). However, it is interesting that adult women who die while bicycling are not often spotlighted in the ways that other less common (via the data) identities are. One exception to this pattern was Kayoko Ishizuka, a cancer researcher at the University of South Florida. Like Niedbalec, her other identity markers bolster her social capital alongside the fact that her death was a hit-and-run. These two factors changed her story into one worth telling various times and by various media outlets (there were 11 news articles written about Ishizuka). The six news stories about the death of Diana Vega also demonstrate her degree of social capital as a woman who was well-known in Tampa's bicycling community; her death brought about discussions of advocacy, spearheaded by local bicyclists. 
As mentioned previously, a plethora of human identity markers intersect to render the image of a full and complex person who is important to and loved by others. When episodic fatality articles point to bicyclists’ age and sex they superficially answer the "Who?” question famously required of journalists, though these markers alone do little for readers' perception of a bicyclist's humanness.

Socioeconomic status. In Goffman’s Stigma (1963), socioeconomic status (SES) is drawn upon as a potentially stigmatizing identity marker that determines a person's character or social value via their household income or employment status. Poverty is often associated with a person’s moral shortcomings, yet is a systemic phenomenon. In Iyengar’s research (1991), participants viewed a videotape showing recent exemplary news stories about poverty. Results found that individuals relied on framing cues to make attributions about poverty (i.e., whose responsibility is it?). When episodic frames were used the individual was responsible (episodic), but when poverty was addressed as a nationwide problem (thematic), the outcomes of it were cast in a more nuanced light. In Aldred's (2013) research, some interviewees said they deliberately dressed in clothing that would distinguish them as a bicyclist in order to garner respect while bicycling; it is worth noting that more than half the interviewees were middle-class and (perhaps) did not want to be confused for someone with a lower SES, so they "dressed the part.”

Figure 6 shows an income map of Hillsborough County. Each red dot signifies the location of a bicyclist fatality; most of which occurred in low income, urban areas. 


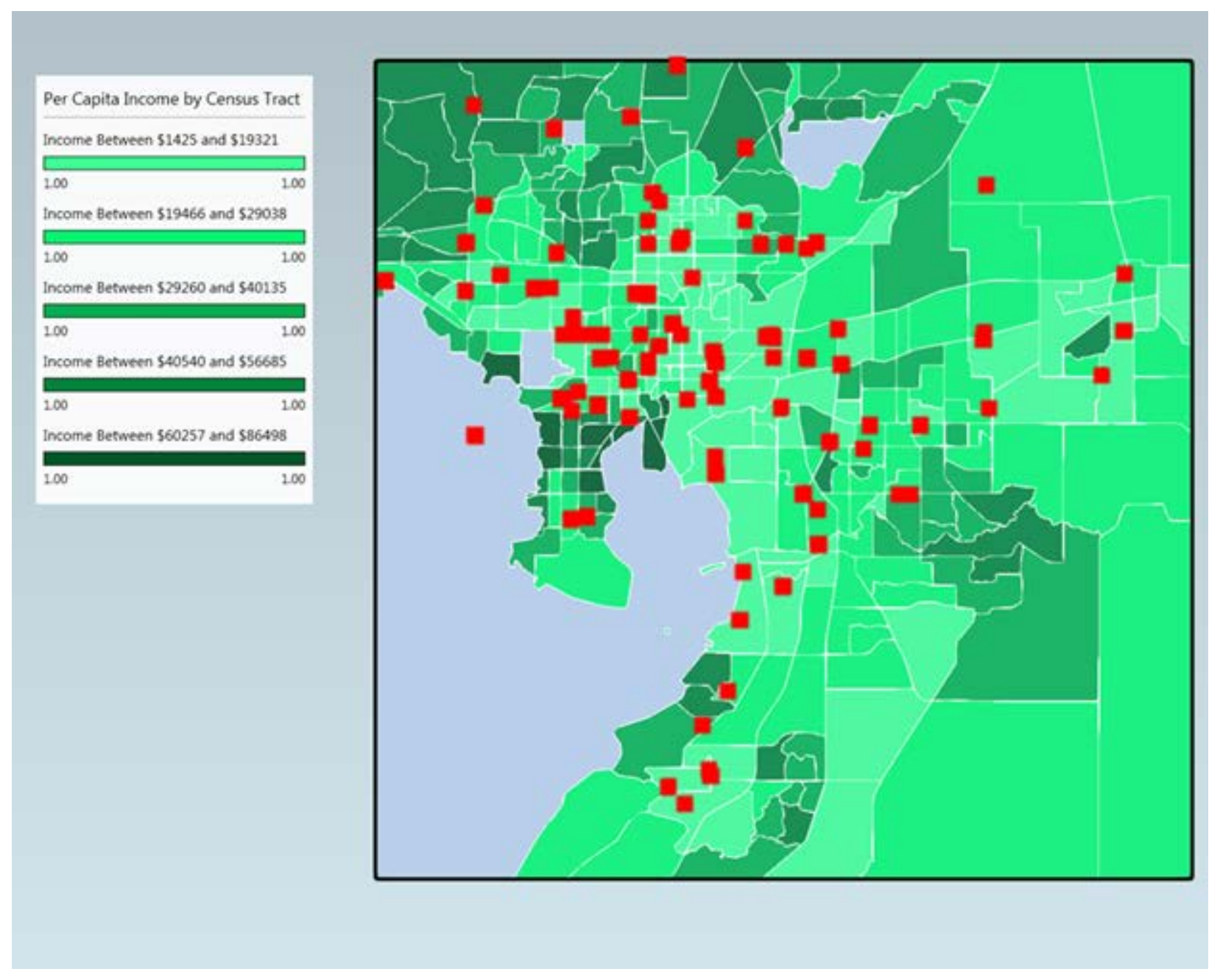

\section{FIGURE 6. Income Levels of Bicyclists via Home Address.}

As previously mentioned in the results section of this report, there are various ways to indicate the approximate socioeconomic status of a bicyclist. An address is one, and with it comes assumptions about the (locally) known area and the people who live in it.

\section{Scripts.}

"While frames represent the entities which can be evoked or referred in the activities represented by schemata, scripts represent the subjects who are involved in these activities, and their relationships,” writes Fairclough (p. 159). For instance, a police officer has a particular script she follows when responding to a traffic crash, and that script defines the relationship 
between the officer and civilians who are involved in the crash. Part of that script is to fill out a police report which, stylistically, is a "form" with prompts for information that contain blank "fields" for the officer to fill in. Discourse analysis would call this form a "text" much like any news report is considered a text and any legal document is considered a text; in other words, it is a site of potential analysis via the textual features that occupy it. In this case, the script is the primary element of the text since the form itself constitutes a script or series of communicative actions that one must follow according to one's social role.

For instance, in police report texts, the vocabulary used to describe the actions of motorists and the actions of bicyclists is different; "no contributing action" is used to describe an absence of responsibility for motorists while "no improper action" is used for bicyclists. The difference between "contributing” and "improper” are significant. "Contributing” is a neutral term that describes action within the context of a relationship, while "improper" is a negative term that describes behavior and is without a relational context. This vocabulary is part of a script that defines social roles (and the power bestowed by those roles) within power relationships.

Another site of potential analysis is in the legal discourse that constitutes what is and is not legal (proper) bicycling behavior. Legal discourse is also a kind of script that is called upon to determine power relationships among social actors. A bicycle is determined a legal vehicle by Florida law (Florida Bicycle Association, 2017) but the law is written in a way that differentiates the bicyclist from the motorist. It reads as follows: "As a driver, a cyclist must follow the traffic rules common to all drivers. As the driver of a bicycle, you must also obey rules developed specifically for bicycles" (p. 5). One point of interest in this example is the word "obey" versus the word "follow" which is used to mandate drivers' behaviors. Following the law means a 
bicyclist must (an imperative) do what is "common to all drivers" (rendering the bicyclist uncommon) while a bicyclist "must obey rules developed specifically for bicycles” (the bicyclist has the capacity to become disobedient and will be punished if caught).

\section{A Formula for Reframing Bicyclists' Deaths in the News}

To start a creative conversation that might begin to prevent bicyclist deaths, the researchers have devised some linguistic strategies that may change the ways in which people view these deaths. As the data have established, the episodic stories may frame the deaths as natural - a series of accidents that happen and are part of the order of things.

Meanwhile, Hillsborough County has taken great strides to prevent these deaths in the past ten years, yet they continue to occur at the same rate. According to Bike/Walk Tampa Bay (2018), a coalition of community partners that formed in 2015, what is desired is cultural change; the results of this study indicate that news reports and language use may impact the ways in which our institutions are willing or able to catalyze positive change at the cultural level.

This is why it is time to start a new conversation about the ways that bicyclists' deaths are framed in news reports. The researchers suggest that attending to language frames, and the ways those frames alter public perception, is one place to start that may not have been considered previously. Language frames impact a public's will to call for and create change.

This new conversation starts with one basic premise; in each of these articles, a person has died of unnatural causes, making the word killed denotatively appropriate (meaning the dictionary definition matches the process that took place in concrete reality). In episodic reports, readers often learns the name, age, and gender of this person. We sometimes learn about where they lived, about crimes they once committed, or if they were under the influence of drugs or alcohol when they died. What we do not learn in these articles is what we read about in all the 
thematically framed news stories: we do not learn about their families, their favorite sports teams, or of the hand life may have dealt them.

The researchers recommend that news reports employ thematic framing when reporting traffic events, moving beyond the details of the events and the parties involved toward a larger discussion of social responsibility for transportation infrastructure and policy reform. In other words, all stories about bicyclists' deaths could be thematic to some extent, regardless of how celebrated they were, how dedicated to cycling they may have been, or what they had the opportunity to achieve before their deaths.

The researchers offer that journalists might continue to give the readership a sense of who a bicyclist was; they were not just a bicyclist. In other words, the stories could include a sense of memorialization and respect for the dead and their kin in the coverage. If the narrative is to begin with the facts of their deaths, then it could also include facts related to the lives they lived. Thematic articles document family members' favorite memories of their loved ones, allowing the readership to make a connection to the deceased as a once-living, breathing human being, just like them.

The researchers also recommend acknowledging the tragedy the driver has suffered as well. The emotional burden the drivers of the vehicles shoulder after being involved in these tragic and often gruesome deaths is traumatic and lasting. Though drivers are often not charged with crimes for bicyclist fatalities, there are other consequences that may be much worse than citations or jail time. Moreover, when the event or the parties involved are mentioned in the news story, the researchers recommend employing active sentences in which the subjects and their actions are clear, to avoid overemphasizing the bicyclist’s responsibility for traffic safety. 
Finally, the word choices made should be considered in terms of their meanings and the ways they might contribute to a common-sense set of assumptions about bicyclist safety.

\section{Conclusion}

The objectives of this research were to 1.) illustrate the nuances of language that shape (and are shaped by) institutional contexts to maintain social order; 2.) evaluate the social effects of a "common sense" or "taken-for-granted" lexicon of transportation; and 3.) develop strategies for participating in transit-related language practices with the aim of altering public perceptions of bicycle fatalities.

In a recent issue of Transportation Research Board, drivers who self-reported aggressiveness toward bicyclists on roadways categorized their behaviors as "teaching them a lesson" and that "they had it coming," claiming that punishing bicyclists (by driving too close to them, etc.) was a way to serve the common good (Piatekowski et al., 2017). If language in local news reports supports the assumption that the bicyclist is a menace to the roadway and should be punished, it is going to make a "Vision Zero" goal to prevent all traffic deaths in Hillsborough County difficult to achieve (Plan Hillsborough, 2018).

In light of this analysis, the researchers offer opportunities in alternative linguistic strategies and thematic framing in the effort to make them available to anybody who wants to change cultural narratives that frame bicyclists negatively. The results suggest that it is important to return to the agreed-upon meanings embedded in our language, question them in the contemporary context of the big picture, and ask what that picture looks like when we describe and interpret it habitually as a culture. If the death of a bicyclist depicts little more than an isolated accident, then it hardly functions as evidence of any kind. But if these deaths allow journalists to tell stories that depict traumatized motorists, grieving families, the tragic nature of 
untimely deaths, the search for answers, and a move toward advocacy, then there is something to work with.

\section{Implications for Future Research}

This project provides a dataset with diverse potential for conducting further research with similar objectives. Future transportation studies should compare textual features of news reports in Hillsborough County to news reports in other areas. Regional differences in vernacular may affect local transportation culture and policy, and henceforth correlate with the frequency of bicyclist fatalities. Other factors viable for comparison include differences in urban environments, infrastructure, and law enforcement policies. For instance, police reports are institutional texts that function to inform media and influence representations of bicyclists, providing yet another source of linguistic data. Traffic laws concerning interactions between motorists and bicyclists are also important to examine. Finally, both this project and potential future projects are viable for replication with a focus on pedestrian fatalities. 


\section{REFERENCES}

2 Cyclists Killed in Separate Crashes. (2013). Retrieved from

http://www.theledger.com/news/20131130/2-cyclists-killed-in-separate-crashes

2 Tampa boys die in bike crashes. (2010). Retrieved from

http://www.heraldtribune.com/article/20100128/News/605200933

14-year-old killed on bicycle in Apollo Beach. (2016). Retrieved from

http://www.wtsp.com/news/14-year-old-killed-on-bicycle-in-apollo-beach/90589656

55-year-old bicyclist killed in Hillsborough County. (2015). Retrieved from http://www.villagesnews.com/55-year-old-bicyclist-killed-in-hillsborough-county/

Aldred, R. (2013). Incompetent or too competent? Negotiation everyday cycling identities in a motor dominated society. Mobilities, 8(2), 252-271.

Apollo Beach Crash Claims Life of Teen Bicyclist. (2016). Retrieved from http://www.tbreporter.com/local-news/teen-bicyclist-dies-apollo-beach-traffic-crash/

Apollo Beach Crash Claims Life of Teen Bicyclist. (2016). Retrieved from http://www.tbreporter.com/local-news/teen-bicyclist-dies-apollo-beach-traffic-crash/

Aronson, S. H. (1951). The sociology of the bicycle. Social Forces, 30(1), 305-312.

Badger, E. (2015). When a car 'crash' isn't an 'accident'-and why the difference matters. The Washington Post. Retrieved from https://www.washingtonpost.com/news/wonk/wp/2015/08/24/when-a-car-crash-isnt-anaccident-and-why-the-difference-matters/

Bartesaghi M. \&, Castor T. (2008). Tracing our steps through communication social construction: Six propositions for how to go on. In (Eds.) G. J. Galanes \& W. LeedsHurwitz, Socially Constructing Communication (225-243). New Jersey: Hampton Press. 
Behrman, E. (2014). Friends stunned by Tampa girl’s hit-and-run death. Retrieved from http://www.tbo.com/news/crime/friends-stunned-by-tampa-girls-hit-and-run-death20140802/

Bicyclist, 16, dies after collision with car in Tampa. (2015). Retrieved from http://www.tampabay.com/news/publicsafety/accidents/bicyclist-dies-after-collisionwith-car-in-tampa/2234467

Bicyclist, 18, dies in Ruskin crash. (2012). Retrieved from http://www.tbo.com/news/bicyclist-dies-in-ruskin-crash-358519

Bicyclist, 18, struck and killed crossing Fletcher Avenue. (2012). Retrieved from http://www.baynews9.com/content/news/baynews9/news/article.html/content/news/articl es/bn9/2012/12/11/bicyclist_18_struck_.html

Bicyclist, 43, killed when car strikes him on U.S. 301 in Valrico, Florida | Accident Data Center. (2015, 2015-07-21T09:03-07:00). Retrieved from https://accidentdatacenter.com/us/florida/tampa-st-petersburgfl/valrico/15/07/21/bicyclist-43-killed-when-car-strikes-him-us-301-valrico-florida

Bicyclist, 43, struck and killed by car on U.S. 301 in Riverview. (2015). Retrieved from http://www.tbo.com/news/traffic/bicyclist-43-struck-and-killed-by-car-on-us-301-inriverview-20150721/

Bicyclist, 56, dies after being hit by van in Gibsonton. (2012). Retrieved from http://www.tbo.com/news/bicyclist--dies-after-being-hit-by-van-in-gibsonton-398407

Bicyclist, 78, dies after being hit by car in Plant City. (2012). Retrieved from http://www.tbo.com/plant-city/bicyclist--dies-after-being-hit-by-car-in-plant-city-393500 Bicyclist crossing U.S. 301 fatally struck by pickup. (2011). Retrieved from 
http://www.tbo.com/news/bicyclist-crossing-us--fatally-struck-by-pickup-340306

Bicyclist dies on N 50th Street in southeast Tampa. (2014). Retrieved from

http://www.baynews9.com/content/news/baynews9/news/article.html/content/news/articl es/bn9/2014/7/19/bicyclist_killed_in_.html

Bicyclist fatally struck crossing North Tampa street, troopers say. (2012). Retrieved from http://www.tbo.com/news/bicyclist-fatally-struck-crossing-north-tampa-street-troopers$\underline{\text { say-580591 }}$

Bicyclist hit by car on I-4 exit ramp and dies. (2014). Retrieved from http://www.tampabay.com/news/publicsafety/accidents/bicyclist-hit-by-car-on-i-4-exitramp-and-dies/2183989

Bicyclist hit, killed at Apollo Beach. (2016). Retrieved from http://www.fox13news.com/news/local-news/109989736-story

Bicyclist hospitalized after hit-and-run in Tampa. (2013). Retrieved from http://www.tbo.com/news/crime/bicyclist-hospitalized-after-hit-and-run-in-tampab82495534z1

Bicyclist in Tampa hit-and-run dies from injuries. (2013). Retrieved from http://www.tbo.com/news/crime/bicyclist-in-tampa-hit-and-run-dies-from-injuriesb82495881z1

Bicyclist killed crossing Hillsborough Avenue. (2014).

Bicyclist killed in Brandon crash. (2015). Retrieved from http://www.abcactionnews.com/news/region-east-hillsborough/brandon/bicyclist-killedin-brandon-crash

Bicyclist killed in crash on US Hwy 301. (2013). 
Bicyclist killed in Dec. 2 U.S. 41 crash identified. (2015). Retrieved from http://www.tbo.com/news/traffic/bicyclist-killed-in-dec-2-us-41-crash-identified20151207/

Bicyclist killed in Dover hit-and-run. (2011). Retrieved from http://www.tampabay.com/news/publicsafety/accidents/bicyclist-killed-in-dover-hit-andrun/1207828

Bicyclist killed in Hillsborough County. (2014). Retrieved from http://www.baynews9.com/content/news/baynews9/news/article.html/content/news/articl es/bn9/2014/10/16/bicyclist_killed_in_.html

Bicyclist killed on I-4 ramp in Hillsborough. (2014). Retrieved from http://www.tbo.com/news/crime/bicyclist-killed-on-i-4-ramp-in-hillsborough-20140611/

Bicyclist seriously hurt by hit-and-run driver in Tampa. (2016). Retrieved from http://www.wtsp.com/news/bicyclist-seriously-hurt-by-hit-and-run-driver-intampa/78951765

Bike/Walk Tampa Bay (2015). About Us. Retrieved from http://www.bikewalktampabay.org/about/

Bracco, B. (2014). Gulf High School mourns Tony Greene, stuck hit and killed on bicycle. Retrieved from http://www.theglobaldispatch.com/gulf-high-school-mourns-tony-greenestuck-hit-and-killed-on-bicycle-62477/

Brady, K. (2011). Seffner Bicyclist Dies in Collision on State Road 60 and Valrico Road. Retrieved from https://patch.com/florida/brandon/seffner-bicyclist-dies-in-collision-onstate-road-60-8930e5bb58

Catalanello, R. (2010). Lutz boy dies after being hit by car while riding bike. Retrieved from 
http://www.tampabay.com/news/publicsafety/accidents/lutz-boy-dies-after-being-hit-bycar-while-riding-bike/1068545?postCode=201

Collision Kills Plant City Bicyclist. (2013). Retrieved from http://www.theledger.com/article/20130814/News/608087155

Cowan, K. (2016). Tampa police searching for hit and run driver. Retrieved from http://www.fox13news.com/news/local-news/111209616-story

Cyclist dies in Tampa after collision with truck. (2013). Retrieved from http://www.tampabay.com/news/publicsafety/accidents/cyclist-dies-in-tampa-aftercollision-with-truck/2151532

Dangerfield, D. (2013). Bicyclist in Tampa hit-and-run dies. Retrieved from http://www.baynews9.com/content/news/baynews9/news/article.html/content/news/articl es/bn9/2013/5/24/bicyclist_in_tampa_h.html

Danielson, R., Vander Velde, J., \& Silva, C. (2017). Son of former Gov. LeRoy Collins struck, killed on bike in Tampa. Retrieved from http://www.tampabay.com/news/publicsafety/accidents/son-of-former-gov-leroy-collinsstruck-killed-on-bike-in-tampa/1111847

Deputies: Tampa woman dies after crashing bicycle into truck. (2013). Retrieved from http://www.baynews9.com/content/news/baynews9/news/article.html/content/news/articl es/bn9/2013/12/10/tampa_bicyclist_kill.html

Driver convicted in bicyclist's death near USF in 2011. (2014). Retrieved from http://www.mynews13.com/content/news/cfnews13/news/article.html/content/news/articl es/bn9/2014/2/4/driver_convicted_in_.html

Driver runs over bicyclist, drives away, Hillsborough deputies say. (2011). Retrieved from 
http://www.tbo.com/news/driver-runs-over-bicyclist-drives-away-hillsborough-deputiessay-340584

Elderly man on tricycle killed in collision in Citrus Park. (2014). Retrieved from http://www.tbo.com/news/traffic/elderly-man-on-tricycle-killed-in-collision-in-citruspark-20141118/

Fairclough, N. (1989). Language and Power. Routledge, New York.

Fairclough, N. (2003). Analyzing Discourse: Textual Analysis for Social Research. Routledge, New York.

FHP releases name of Tampa bicyclist killed last week in crash with van. (2015). Retrieved from http://www.tampabay.com/news/publicsafety/accidents/fhp-releases-name-of-tampabicyclist-killed-last-week-in-crash-with-van/2256861

Florida Bicycle Association (2017). Florida bicycle law enforcement guide: A review of Florida's bicycle traffic laws to help with warnings, citations and crash reports. Retrieved from https://floridabicycle.org/wpcontent/uploads/2018/08/PEGLEG_winter2017BIKE.pdf

Florida’s Integrated Report Exchange System (2018). Quick stats. Retrieved from https://www.firesportal.com/Pages/Public/QuickStats.aspx

Former Senate candidate dies in cycling accident. (2010). Retrieved from http://www.heraldtribune.com/article/20100729/News/605212931

Gibsonton cyclist hit by car, hospitalized. (2014). Retrieved from http://www.tampabay.com/news/publicsafety/accidents/cyclist-hit-by-carhospitalized/2160735 
Gitlin, T. (1980). The whole world is watching: Mass media in the making and unmaking of the New Left. University of California Press, Berkeley.

Glassford, C. (2014). Family, friends raising funds for Tampa girl killed in hit-and-run. Retrieved from http://www.baynews9.com/content/news/baynews9/news/article.html/content/news/articl es/bn9/2014/8/3/fundraiser.html

Glassford, C. (2014). Man arrested in hit-and-run didn't have valid driver's license. Retrieved from http://www.baynews9.com/content/news/baynews9/news/article.html/content/news/articl es/bn9/2014/8/4/man_arrested_in_hit_html

Gomez, G. (2016). DUI driver gets 12 years for killing bicyclist. Retrieved from http://www.fox13news.com/news/local-news/84896945-story

Goffman, E. (1986). Frame analysis: An essay on the organization of experience. Northeastern University Press, New England.

Grandmother remembers boy who died in 1 of 2 bike crashes. (2010). Retrieved from http://www.tbo.com/news/grandmother-remembers-boy-who-died-in--of--bike-crashes51612

Highway patrol identifies Brandon bicyclist struck and killed by pickup truck. (2016). Retrieved from http://web.tampabay.com/news/publicsafety/accidents/highway-patrol-identifiesbrandon-bicyclist-struck-and-killed-by-pickup/2292619

Hillsborough crash Kills Bicyclist. (2016).

Hit-and-run driver kills bicyclist in Tampa. (2016). Retrieved from http://wfla.com/2016/11/27/bicyclist-hit-and-killed-in-tampa/ 
Hillsborough deputies ID bicyclist killed in wreck. (2010). Retrieved from http:/www.tbo.com/brandon/hillsborough-deputies-id-bicyclist-killed-in-wreck-37075

Hojman, P., Ortuzar, J. D. D., \& Rizzi, L. I. (2005). On the joint valuation of averting fatal and severe injuries in highway accidents. Journal of Safety Research 36, 377-386.

Houck, J. (2010). LeRoy Collins Jr.'s death a call to action for bike safety. Retrieved from http://www.tbo.com/lifestyles/life/2010/dec/22/leroy-collins-jrs-death-a-call-to-actionfor-bike--ar-21222/

Iyengar, S. (1991). Is anyone responsible? How television frames political issues. University of Chicago Press.

Iyengar, S., \& Kinder, D. R. (1987). News that matters: Television and American opinion. University of Chicago Press.

Kline, R. \& Pinch, T. (1996). Users as agents of technological change: The social construction of the automobile in the rural United States. Technology and Culture, 37(4), 763-795.

Knight, K. (2010). Colleague drove car that struck Chiles Elementary teacher. Retrieved from http://www.tbo.com/northeast-tampa/colleague-drove-car-that-struck-chiles-elementaryteacher-31830

Kucyk, K. (2013). Man hit and killed by unknown drive while riding bike.

Lang, M. (2012). Deaths spur the state to push pedestrian and cyclist safety. Retrieved from http://www.heraldtribune.com/article/20120804/News/605212349

League of American Bicyclists (2014). Every Bicyclist Counts. Retrieved from https://bikeleague.org/sites/default/files/EBC_report_final.pdf

Levesque, W. R. (2014). Bicyclists rally in Tampa for roadway safety. Retrieved from http://www.tampabay.com/news/publicsafety/bicyclists-rally-in-tampa-for-roadway- 
safety/2173842

LeRoy Collins, Jr. Dies in Bike Accident | The Jacksonville Observer. (2010). Retrieved from http://www.jaxobserver.com/2010/07/29/leroy-collins-jr-dies-in-bike-accident/

LeRoy Collins Jr., son of former Florida governor, dies in bike accident. (2010). Retrieved from http://jacksonville.com/news/florida/2010-07-29/story/leroy-collins-jr-son-formerflorida-governor-dies-bike-accident

Lonon, S. (2014). Motorized Bike Rider Killed on Sheldon Road. Retrieved from https://patch.com/florida/westchase/motorized-bike-rider-killed-sheldon-road-0

Lonon, S. (2015). Bicyclist Killed in Brandon Crash. Retrieved from https://patch.com/florida/brandon/bicyclist-killed-brandon-crash-0

Lonon, S. (2016). Brandon Bicyclist Killed in Crash Identified. Retrieved from https://patch.com/florida/brandon/brandon-bicyclist-killed-crash-identified

Lutz bicyclist, Riverview motorcyclist die in unrelated crashes. (2012). Retrieved from http://www.tbo.com/pasco-county/lutz-bicyclist-riverview-motorcyclist-die-in-unrelatedcrashes-382288

Magusin, H. (2017). If you want to get away with murder, use your car: A discursive content analysis of pedestrian traffic fatalities in news headlines. Earth Common Journal 7(1), 65-97.

MacRitchie, V. \& Seedat, M. (2008). Headlines and discourses in newspaper reports on traffic accidents. South African Journal of Psychology, 38(2), 337-354.

Maloney, E. (2013). Bicyclist killed in hit-and-run while riding to work. Man lying in road in Tampa run over by car, dies. (2014). Retrieved from http://www.tampabay.com/news/publicsafety/accidents/bicyclist-killed-in-tampa- 
$\operatorname{crash} / 2189178$

Man Sentenced for Bicyclist's Death. (2014). Retrieved from

http://www.theledger.com/news/20140309/man-sentenced-for-bicyclists-death

Meacham, A. (2012). 'Happy camper' and volunteer Ken Hamlin lived a double life. Retrieved from http://web.tampabay.com/news/obituaries/happy-camper-and-volunteer-kenhamlin-lived-a-double-life/1222960

Mele, L. M., \& B. M. Bello (2007). Coaxing and coercion in roadblock encounters on Nigerian highways. Discourse \& Society, 18(4), 437-452.

Michael, M. (2016). Bicyclist killed, hit by 2 vehicles on Dale Mabry Hwy. Retrieved from http://wfla.com/2016/08/23/bicyclist-killed-hit-by-2-vehicles-on-dale-mabry-hwy/

Morales, I., \& Valentine, D. (2010). Bicyclist ninth to die on Tampa Bay area roads in recent months. Retrieved from http://www.tampabay.com/news/publicsafety/accidents/bicyclistninth-to-die-on-tampa-bay-area-roads-in-recent-months/1134552

Morales, I., \& Valentine, D. (2011). Family finally claims remains of veteran killed on bicycle in Hillsborough. Retrieved from http://www.tampabay.com/news/humaninterest/familyfinally-claims-remains-of-veteran-killed-on-bicycle-in-hillsborough/1157918

Morales, I., \& Valentine, D. (2011). Unclaimed remains of veteran killed on bicycle in Tampa to be buried in Bushnell. Tampa Bay Times. Retrieved from http://www.tampabay.com/news/military/veterans/unclaimed-remains-of-veteran-killedon-bicycle-in-tampa-to-be-buried-in/1143689

Morel, L. C. (2012). Bicyclist, 18, killed in Tampa crash. Retrieved from http://www.tampabay.com/news/publicsafety/accidents/bicyclist-18-killed-in-tampacrash/1265599 
Morel, L. C. (2012). Woman arrested in crash that killed 78-year-old bicyclist. Tampa Bay Times. Retrieved from http://www.tampabay.com/news/publicsafety/crime/womanarrested-in-crash-that-killed-78-year-old-bicyclist/1247547

Morel, L. C. (2013). Bicyclist dies after hit-and-run accident in Tampa. Retrieved from http://www.tampabay.com/news/publicsafety/crime/police-searching-for-hit-and-rundriver-in-tampa/2122644

Merriam-Webster (2018). Incident. Retrieved from https://www.merriamwebster.com/dictionary/incident

Morelli, K. (2010). Police ID bicyclist killed in Tampa wreck. Retrieved from http://www.tbo.com/news/crime/police-id-bicyclist-killed-in-tampa-wreck-26791

National Highway Traffic Safety Administration (2018). Research \& data. U.S. Department of Transportation. Retrieved from https://www.nhtsa.gov/research-data

Parker, I. (1992) Discourse dynamics: Critical analysis for social and individual psychology. Routledge, London.

Peterson, Z. (2014). Tampa bicyclist dies after hit by car on I-4 ramp. Retrieved from http://www.tampabay.com/news/publicsafety/accidents/tampa-bicyclist-dies-after-hit-bycar-on-i-4-ramp/2184049

Piatkowski, D. P., Marshall, W., \& Johnson, A. S. (2017). Bicyclist Backlash: Qualitative Examination of Aggressive Driver-Bicyclist Interactions. Transportation Research Board. Retrieved from https://doi.org/10.3141/2662-03

Plan Hillsborough (2018). Vision Zero Hillsborough. Retrieved from http://www.planhillsborough.org/vision-zero/

Police arrest suspect in hit and run that left bicyclist injured. (2016). Retrieved from 
http://www.fox13news.com/home/105960213-story

Police seeking driver after bicyclist struck in hit and run. (2016). Retrieved from http://wfla.com/2016/03/12/police-seeking-driver-after-bicyclist-struck-in-hit-and-run/

Poltilove, J. (2010). Police: No charges in cycling death of ex-governor's son.

Poltilove, J. (2010). Tampa bicyclist killed after being struck. Retrieved from http://www.tbo.com/news/tampa-bicyclist-killed-after-being-struck-14981

Reeves, M. (2016). South Florida driver faces DUI manslaughter charge in death of bicyclist on Howard Frankland Bridge. Retrieved from http://www.tampabay.com/news/publicsafety/accidents/south-florida-driver-arrested-indeath-of-bicyclist-on-howard-frankland/2283727

Reyes, R. (2013). Arrest made in fatal hit and run involving Tampa bicyclist. Retrieved from http://www.tbo.com/news/breaking-news/arrest-made-in-fatal-hit-and-run-involvingtampa-bicyclist-20130807/

Rossetter, S. (2011). Bicyclist struck and killed in Valrico early Saturday. Retrieved from http://www.tampabay.com/news/publicsafety/accidents/bicyclist-struck-and-killed-invalrico-early-saturday/1190858

Rossetter, S. (2012). Bicyclist struck and killed along U.S. 41 in Gibsonton. Retrieved from http://www.tampabay.com/news/publicsafety/accidents/bicyclist-struck-and-killed-alongus-41-in-gibsonton/1216036

Ruskin boy on bicycle killed in collision with vehicle. (2016). Retrieved from http://www.bradenton.com/news/local/crime/article67205852.html

Sanders, K. (2010). Bicyclist killed in collision with truck in Tampa. Retrieved from http://www.tampabay.com/news/publicsafety/accidents/bicyclist-killed-in-collision-with- 
truck-in-tampa/1072178

Sheehan, K. (2014). Man charged in hit-run death Tampa girl, 12. Retrieved from http://www.tampabay.com/news/publicsafety/accidents/hit-and-run-crash-in-tampaseriously-injures-girl/2191183

Silvestrini, E. (2014). Tampa man gets 13-year sentence in bicyclist's death. Retrieved from http:/www.tbo.com/news/crime/tampa-man-gets-13-year-sentence-in-bicyclists-death20140307/

Smart Growth America (2018). What are Complete Streets? Retrieved from https://smartgrowthamerica.org/program/national-complete-streetscoalition/publications/what-are-complete-streets/

Spencer, C. (2016). Bicyclist seriously injured in Tampa hit-and-run. Retrieved from http://www.abcactionnews.com/news/region-tampa/bicyclist-seriously-injured-in-tampahit-and-run

Spencer, C. (2016). Teen dies after being hit by car. Retrieved from http://www.abcactionnews.com/news/region-hillsborough/teen-dies-after-being-hit-bycar

Stanley, K. (2010). Tampa Bay has had nine bicycle fatalities in just over four months. Retrieved from http://www.tampabay.com/news/publicsafety/tampa-bay-has-had-nine-bicyclefatalities-in-just-over-four-months/1138362

Sullivan, D. (2010). Two Hillsborough boys hit, killed on bicycles in two days. Tampa Bay Times. Retrieved from http://www.tampabay.com/news/publicsafety/accidents/twohillsborough-boys-hit-killed-on-bicycles-in-two-days/1068586?postCode=201

Sullivan, D. (2014). Driver who killed bicyclist near USF given 13 years in prison. Retrieved 
from http://www.tampabay.com/news/courts/criminal/driver-who-killed-bicyclist-nearusf-given-13-years-in-prison/2169061

Tampa 18-year-old on bicycle struck, killed by vehicle. (2014). Retrieved from http://www.tbo.com/news/crime/tampa-18-year-old-on-bicycle-struck-killed-by-vehicle20141016/

Tampa Bicyclist Dies in Crash. (2016). Retrieved from http://www.tbreporter.com/localnews/hillsborough/bicyclist-killed-hillsborough-crash/

Tampa bicyclist killed after riding into path of vehicle. (2016). Retrieved from http://www.wtsp.com/news/tampa-bicyclist-killed-after-riding-into-path-ofvehicle/305669800

Tampa teen riding bike struck by truck, dies. (2011). Retrieved from http://www.tbo.com/news/tampa-teen-riding-bike-struck-by-truck-dies-247079

Tampa Man Accused of Hitting Bicyclist and Fleeing Scene. (2016). Retrieved from http://www.tbreporter.com/crime/tampa-man-charged-hit-run-bicyclist/

Tampa man killed while riding motorized vehicle. (2014). Retrieved from http://www.tampabay.com/news/tampa-man-killed-while-riding-motorizedvehicle/2206985

Tampa police arrest driver of Ford truck seen in area of fatal hit-and-run crash. (2016). Retrieved from http://www.tampabay.com/news/publicsafety/tampa-police-looking-for-driver-offord-truck-seen-in-area-of-fatal/2270814

Tampa police arrest hit-and-run suspect. (2016). Retrieved from http://www.tbo.com/news/traffic/tampa-police-arrest-hit-and-run-suspect-20160313/ Tampa police search for driver in hit-and-run that injured bicyclist. (2016). Retrieved from 
http://www.tampabay.com/news/publicsafety/accidents/tampa-police-search-for-driverin-hit-and-run-that-injured-bicyclist/2269116

Tampa teen on bike struck, killed on Gunn Highway. (2014). Retrieved from http://www.mynews13.com/content/news/cfnews13/news/article.html/content/news/articl es/bn9/2014/1/7/tampa_teen_on_bike_s.html

Tampa woman on bicycle dies in collision with pickup. (2013). Retrieved from http://www.tbo.com/news/tampa-woman-on-bicycle-dies-in-collision-with-pickup20131210/

Tate Grad Killed In Tampa Hit And Run Wreck. (2013). Retrieved from http://www.northescambia.com/2013/08/tate-grad-killed-in-tampa-hit-and-run-wreck Taylor, C. (2012). UPDATE: Bicyclist Hurt In Crash Dies From Injuries. Lutz Patch. Retrieved from https://patch.com/florida/lutz/update-bicyclist-hurt-in-crash-dies-from-injuries

Teen bicyclist killed on Gunn Highway. (2014). Retrieved from http://www.abcactionnews.com/news/region-hillsborough/teen-bicyclist-killed-on-gunnhighway

Teen cyclist hit, killed crossing against red light on Tampa's Waters Avenue. (2014). Tampa Bay Times. Retrieved from http://www.tampabay.com/news/publicsafety/accidents/teencyclist-hit-killed-crossing-against-red-light-on-tampas-waters-avenue/2202381

Teen on bicycle killed after being hit by car in Apollo Beach. (2016). Retrieved from http://www.tbo.com/news/traffic/teen-on-bicycle-killed-after-being-hit-by-car-in-apollobeach-20160319/

Teen on bike dies in collision on Gunn Highway. (2014). Retrieved from http://www.tbo.com/news/teen-on-bike-dies-in-collision-on-gunn-highway-20140107/ 
Trenkman, C. (2013). Ruskin residents stunned after hit and run crash. Retrieved from http://www.abcactionnews.com/news/ruskin-residents-stunned-after-hit-and-run-crash Truck fatally strikes bicyclist in Tampa intersection. (2013). Retrieved from http://www.tbo.com/news/truck-fatally-strikes-bicyclist-in-tampa-intersection-20131108/ Truck leaves scene after fatally striking bicyclist on U.S. 301. (2010). Retrieved from http://www.tbo.com/northeast-tampa/truck-leaves-scene-after-fatally-striking-bicycliston-us--65204

Two bicyclists killed in Hillsborough crashes. (2013). Tampa Bay Times. Retrieved from http://www.tampabay.com/news/two-bicyclists-killed-in-hillsborough-crashes/2154856

Two cyclists killed in separate crashes. (2013). Retrieved from http://www.tbo.com/two-cyclistskilled-in-separate-crashes-20131130/

Two cyclists killed in separate crashes. (2013). Retrieved from http://www.tbo.com/two-cyclistskilled-in-separate-crashes-20131130/

United States Census Bureau (2017). Quick facts: Hillsborough County, Florida. Retrieved from https://www.census.gov/quickfacts/fact/table/hillsboroughcountyflorida/PST120217.

Valentine, D. (2010). LeRoy Collins Jr., Son of Former Fla. Gov., Killed in Tampa Bicycle Accident. Retrieved from http://www.theledger.com/article/20100729/news/608088006

Valentine, D. (2010). Scientist who died on bike was among USF's 'best and brightest'. Retrieved from http://www.tampabay.com/news/publicsafety/crime/scientist-who-died-on-bikewas-among-usfs-best-and-brightest/1124500

Valentine, D. (2012). Plant City cyclist, 29, killed in collision with Jeep in Dover. Retrieved from http://www.tampabay.com/news/publicsafety/plant-city-cyclist-29-killed-incollision-with-jeep-in-dover/1210115 
Valrico bicyclist dies after being struck by car on U.S. 301. (2015). Retrieved from http://www.baynews9.com/content/news/baynews9/news/article.html/content/news/articl es/bn9/2015/7/21/biccylist_dies_after.htmlVander Velde, J. (2010). 2nd car caused bicyclist's death, witness says. Retrieved from http://www.tampabay.com/news/publicsafety/2nd-car-caused-bicyclists-death-witnesssays/1133707

Vander Velde, J. (2010). Arrest made in hit-and-run death of USF bicyclist.

Vander Velde, J. (2010). Ghosts of Tampa bicyclists linger in mind and metal. Retrieved from http://www.tampabay.com/news/publicsafety/ghosts-of-tampa-bicyclists-linger-in-mindand-metal/1131109

Vander Velde, J. (2011). Hillsborough deputies search for driver accused of hitting Dover bicyclist. Retrieved from http://www.tampabay.com/news/publicsafety/hillsboroughdeputies-search-for-driver-accused-of-hitting-dover-bicyclist/1207866

Vander Velde, J. (2011). Veterinarian and judo instructor Robert Niedbalec killed in bike crash. Tampa Bay Times. Retrieved from http://www.tampabay.com/news/publicsafety/veterinarian-and-judo-instructor-robertniedbalec-killed-in-bike-crash/1151609

Vander Velde, J. (2012). Lutz bicyclist hit by car last week dies. Retrieved from http://www.tampabay.com/news/publicsafety/lutz-bicyclist-hit-by-car-last-weekdies/1262625

Vander Velde, J. (2012). Tampa Bay bicycle deaths rise in 2012. Tampa Bay Times. Retrieved from http://www.tampabay.com/news/publicsafety/tampa-bay-bicycle-deaths-rise-in$2012 / 1268303$ 
Vander Velde, J. (2013). Bicyclist hit, killed in western Hillsborough County.

Vander Velde, J. (2014). Bicyclist, 16, dies in collision with truck in Odessa. Retrieved from http://www.tampabay.com/news/publicsafety/accidents/bicyclist-16-dies-in-collisionwith-truck-in-odessa/2159951

Vigil held for Tampa girl killed in hit-and-run crash. (2014). Retrieved from http://www.baynews9.com/content/news/baynews9/news/article.html/content/news/articl es/bn9/2014/8/2/person_of_interest_d.htmlTroopers ID bicyclist killed in East Tampa collision. (2015). Retrieved from http://www.tbo.com/news/traffic/brandon-bicyclistkilled-in-crash-on-mlk-blvd-20150223/

Wantuck Giles, S. (2010). Former admiral LeRoy Collins Jr. killed in bicycle accident. Retrieved from WUSF Public Media website: http://wusftv.usf.edu/news/2010/07/29/former_admiral_leroy_collins_jr_killed_in_bicyc le_accident

Williams, C. (2013). Man killed in hit-and-run crash on overpass at I-4 and U.S. 301. Retrieved from http://www.abcactionnews.com/news/region-hillsborough/possible-hit-and-runfatal-at-i-4-301

Wilson, S. (2012). Deadly crash detours traffic off Highway 41 in Ruskin for several hours. Retrieved from http://hillsboroughcounty.wtsp.com/news/news/105240-deadly-crashdetours-traffic-highway-41-ruskin-several-hours

Wolski, K. (2011). Daughter: Dad died doing what he loved most: biking. Retrieved from http://www.baynews9.com/content/news/baynews9/news/article.html/content/news/articl es/ot/both/2011/02/14/Daughter_Dad_died_doing_what_he_loved_most_biking.html 